University of Louisville

ThinkIR: The University of Louisville's Institutional Repository

Electronic Theses and Dissertations

$8-2010$

\title{
The personal and social benefits of airplane piloting as a serious leisure activity for women.
}

Frances Louise Shupe 1956-

University of Louisville

Follow this and additional works at: https://ir.library.louisville.edu/etd

\section{Recommended Citation}

Shupe, Frances Louise 1956-, "The personal and social benefits of airplane piloting as a serious leisure activity for women." (2010). Electronic Theses and Dissertations. Paper 1325.

https://doi.org/10.18297/etd/1325

This Master's Thesis is brought to you for free and open access by ThinkIR: The University of Louisville's Institutional Repository. It has been accepted for inclusion in Electronic Theses and Dissertations by an authorized administrator of ThinkIR: The University of Louisville's Institutional Repository. This title appears here courtesy of the author, who has retained all other copyrights. For more information, please contact thinkir@louisville.edu. 
THE PERSONAL AND SOCIAL BENEFITS OF AIRPLANE PILOTING AS A SERIOUS LEISURE ACTIVITY FOR WOMEN

\title{
By
}

Frances Louise Shupe

B.G.S., Virginia Commonwealth University, 1987

\author{
A Thesis \\ Submitted to the Faculty of the \\ College of Arts and Sciences of the University of Louisville \\ in Partial Fulfillment of the Requirements \\ for the Degree of
}

\section{Master of Arts}

\author{
Department of Sociology \\ University of Louisville \\ Louisville, Kentucky
}

August 2010 
Copyright 2010 by Frances Louise Shupe

All rights reserved 

THE PERSONAL AND SOCIAL BENEFITS OF AIRPLANE PILOTING AS A SERIOUS LEISURE ACTIVITY FOR WOMEN

\author{
By \\ Frances Louise Shupe \\ B.G.S., Virginia Commonwealth University, 1987
}

A Thesis Approved on

July 29,2010

By the following Thesis Committee:

Thesis Irirector 


\section{ACKNOWLEDGMENTS}

I would like to thank my thesis committee chair, Dr. Patricia Gagné, for her guidance, assistance, and suggestions on this project. I would also like to thank the other members of my committee, Dr. Mark Austin and Dr. Karen Christopher, for their suggestions and assistance. Lastly, I would like to thank my partner, Mia Coleman, for her patience and support throughout this process. 


\section{ABSTRACT \\ THE PERSONAL AND SOCIAL BENEFITS OF AIRPLANE PILOTING AS A SERIOUS LEISURE ACTIVITY FOR WOMEN \\ Frances Louise Shupe}

July 29,2010

Serious leisure theory (Stebbins, 1992) is used to frame this examination of women's long-term involvement in airplane piloting. Through in-depth, semi-structured telephone and e-mail interviews with women having over 15 years experience as private pilots, this study examines their leading motivations and their personal and social benefits realized through airplane piloting as a leisure activity. Women's participation in amateur airplane piloting displays the six characteristics of serious leisure. In addition to the durable benefits ascribed to serious leisure, the respondents demonstrated several other personal and social benefits. The interview data revealed that women pursue airplane piloting as independent, interdependent, or dependent pilots. I identified independent pilots as the women who were intrinsically motivated to become involved with piloting for selforiented rewards. Interdependent pilots who decided with their significant others to engage in airplane piloting as a shared leisure activity demonstrates internalization of extrinsic motivation. Dependent pilots are women whose partner had already been piloting for years before they are extrinsically motivated to pursue their pilot certificates in order to assist their partners. Using grounded theory analysis and feminist research 
methodology, this study allowed a comparison of benefits realized from airplane piloting as serious leisure based upon women's initial motivations to become pilots. This study of women airplane pilots enabled insight into women's involvement in a male dominated serious leisure that requires a significant investment of time, effort and money in the acquisition and maintenance of specialized skills. 


\section{TABLE OF CONTENTS}

PAGE



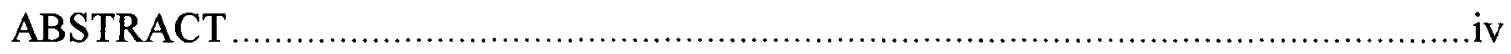

CHAPTER

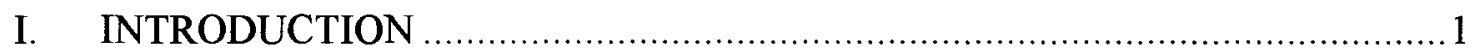

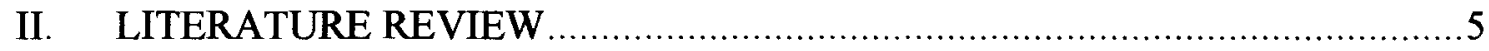

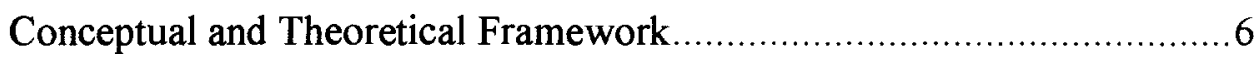

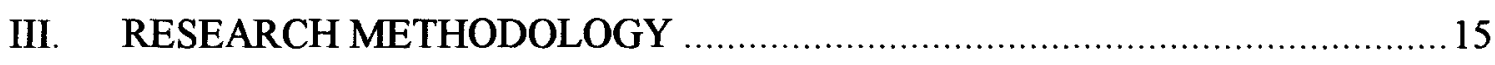

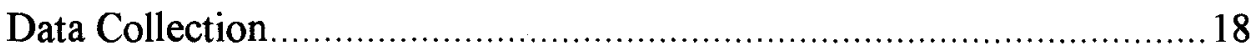

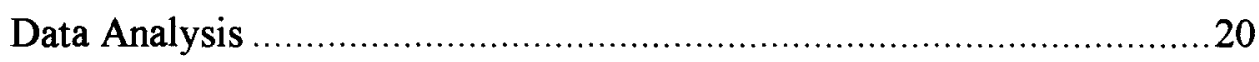

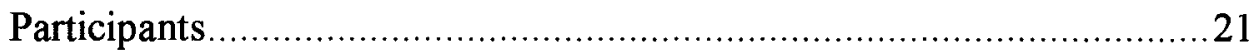

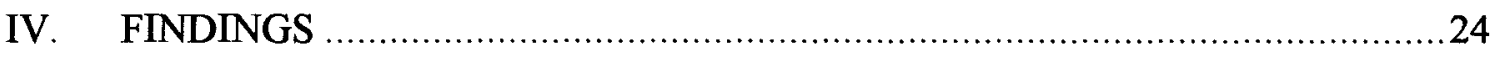

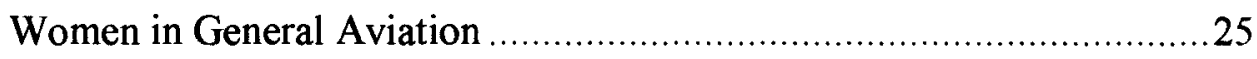

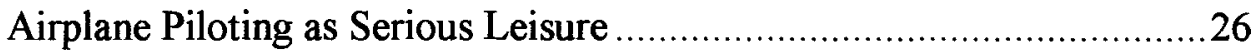

Motivations to Become Airplane Pilots ...................................................30



Personal and Social Benefits of Amateur Airplane Piloting.....................38

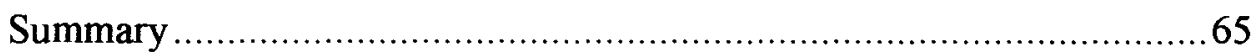

V. DISCUSSION

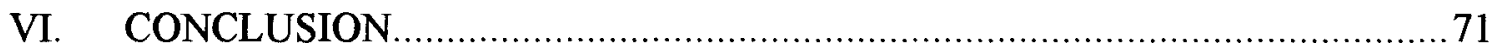




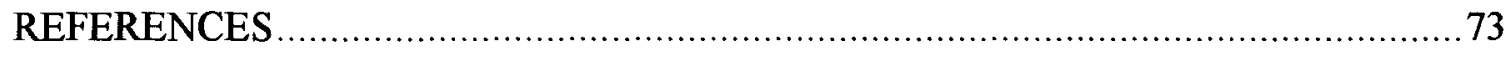

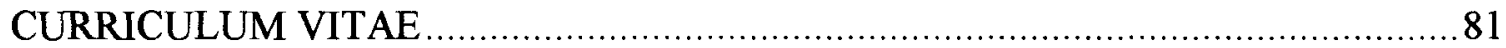




\section{CHAPTER I}

\section{INTRODUCTION}

At the 2003 Northeastern Recreation Research Symposium held in Bolton Landing, New York by the Forest Service of the United States Department of Agriculture, an exploratory research applied the theory of serious leisure to the recreational flying of remote control model airplanes and experimental light aircrafts. The report confirmed that the characteristics of serious leisure are found in the participation of these forms of recreational flying (Wang, 2003). This present study builds upon the prior application of serious leisure to flying by focusing on women's long-term leisure pursuit as private pilots.

By interviewing women with long-term involvement in airplane piloting as a leisure activity, it is possible to discover the various benefits realized from this form of serious leisure participation. The goals of this study are to discover piloting women's leading motivations and the personal and social benefits derived from flying. Serious leisure is a sociological theory developed to gain understanding of the pursuit of leisure (Stebbins, 1992). According to this theory, leisure is found through engaging in activities that may be either casual or serious in nature. Casual leisure is defined as activities engaged in during free time that provide an immediate reward of pleasure but no longlasting benefits and require no specialized skills or knowledge (Stebbins, 2007). By contrast, serious leisure involves engaging in an appealing leisure activity that requires 
specific skills to perform and in turn provides long-lasting, positive outcomes for participants. Situated between casual leisure and serious leisure is project-based leisure, which has the characteristics of serious leisure without the anticipation of long-term involvement (Stebbins, 2007). In order to participate in airplane piloting as a leisure activity, it is necessary to devote a considerable amount of time, effort, and money to acquire the special skills and knowledge. Airplane pilots must operate aircraft in accordance with Title 14, Part 91 of the Code of Federal Regulations upon earning a government-issued pilot certificate (14 CFR, pt. 91, 2010). Participants in other unique serious leisure pursuits, such as skydiving (Celsi, Rose, and Leigh, 1993; Laurendeau, 2006; Laurendeau and Van Brunschot, 2006; Lipscombe, 1999; Price and Bundesen, 2005) and deep sea diving (Hunt, 1995) obtain certification through non-governmental organizations and are not subject to strict governmental regulations.

Little critical attention has been devoted to the leisure aspect of airplane piloting. Studies that have focused on nonprofessional aviation have dealt with safety and risk (Hunter, 2006), the history of private aviation in America (Meyer, 2009), and the mental health issues of recreational piloting (Sindoni, 2004). The experiences of women pilots have been the focus of doctoral dissertations addressing the psychological experiences of flight training (Valentine, 2001) and the experiences of three middle-aged female pilots (Fessenden, 2002). A study was conducted in which the recreational flying of experimental light aircraft was analyzed as a serious leisure activity (Wang, 2003). However, the literature shows no emphasis on women flying for serious leisure, so this study fills that gap. 
This study contributes to the under-researched subject of women's engagement in serious leisure (Raisborough, 2006). The six characteristics of serious leisure are used to frame the findings of the shared experiences of women with an enduring involvement in an elite leisure activity. Previous studies of women's participation in serious leisure activities have focused on quilters (Stalp, 2006) and Red Hat Society members (Stalp, Radina, and Lynch, 2008). While the literature also includes studies of women in maledominated serious leisure activities, such as sea cadets (Raisborough, 2006), skydivers and snowboarders (Laurendeau and Sharara, 2008), and motorcyclists (Auster, 2001; Gagne and Austin, forthcoming), insufficient attention has been given to their initial motivation that led to their long-term involvement. Therefore, this study addresses women's motivation to pursue airplane piloting as a leisure activity and the personal and social benefits they realized through such involvement.

Research has linked intrinsic motivation to leisure participation, in which a leisure activity is engaged in 'for its own sake' (Csikszentmihalyi, 1990; Deci and Ryan, 1985; Kelly, 1983; Recours, Souville, and Griffet, 2004). As such, it would be expected that individuals choose to engage in a preferred leisure activity for its intrinsic satisfaction and rewards. Personal choice is a key factor in defining an activity as leisure (Kelly, 1983), yet the need for relatedness often leads to engaging in a leisure activity not of one's own choosing (Ryan and Deci, 2000). A framework has been used in looking at motivation of engaging in leisure activities based upon the goal direction of leisure, which looks at leisure as agency or as affiliation (Freysinger, 1995). This study allows an examination of the experiences and rewards realized by female pilots and the different motives that led to their participation. Through the research approach of grounded theory 
(Glaser and Strauss, 1967), this study contributes to a greater understanding of women's long-term involvement in a high-investment serious leisure activity. Through the sensitizing concepts of serious leisure and leisure motivation this study proposes insight into this phenomenon through qualitative data collection and inductive analysis of how motivation impacts the leisure experience and participation among women who fly airplanes for leisure. 


\section{CHAPTER II}

\section{LITERATURE REVIEW}

Sociologists gave little attention to leisure before the latter half of the 20th century. The growth in leisure studies coincided with the increased use of technology in everyday life. Technology has reduced the time needed to perform many necessary functions, thus increasing time for leisure. This shift in focus toward leisure resulted in a new conception of it as diametrically opposed to work. Several definitions of leisure appeared, sharing terms such as free time, free choice, enjoyment, satisfaction, and for its own sake.

There has been a great deal of sociological research on the role of leisure as a phenomenon in the lives of individuals as well as in society as a whole. The definition of leisure is subjective and specific to the many experiences of leisure that exist. Several key aspects of the leisure experience have been identified, although not all aspects are necessary for leisure to be experienced, nor does the presence of these characteristics qualify all activities as leisure. Scholars engaged in the sociological study of leisure agree that leisure has many different meanings. Leisure is defined as a residual time when one is free from obligations and work (Parker, 1976; Stebbins, 2007); a space where one can find enjoyment without guilt (Rojek, 2000); and an experience of enjoyment, escape, relaxation, excitement, development, challenge, and social interaction (Kelly, 1983; Kelly and Freysinger, 2000). Leisure studies assert individuals' universal right to leisure (Arai 
and Pedlar, 2003). This study focuses on the concepts of serious leisure theory to frame women's experiences as amateur airplane pilots. Serious leisure is an analytical perspective used to understand why and how people engage in unique and demanding forms of leisure in which efforts are comparable to the demands of a career (Stebbins, 1992).

\section{Conceptual and Theoretical Framework}

This study is guided by serious leisure theory (Stebbins, 1992, 2004, 2007, 2008), the concepts of intrinsic and extrinsic motivation (Deci and Ryan, 1985, 2000; Ryan and Deci, 2000) and the concepts of dual leisure directed action identified as leisure as affiliation and leisure as agency (Freysinger, 1995). These theories and concepts are integrated to analytically frame the research data (Bowen, 2006).

\section{Serious Leisure Theory}

By definition, leisure provides satisfaction, enjoyment (Kelly, 1983), escape, relaxation, excitement (Kelly and Freysinger, 2000), and durable personal and social benefits (Stebbins, 2007). According to the serious leisure perspective, leisure engagement varies by the amount of effort involved on the part of the participant. Casual leisure requires very little commitment to the activity and few if any special skills to participate. The most common form of casual leisure is watching television. A second form of leisure, project-based leisure, requires one to acquire specialized knowledge and skills in order to participate in the activity, without the expectation of long-term involvement. Examples of project-based leisure include one-time volunteer efforts, do-ityourself home projects, and one-time outdoor adventure trips such as white-water rafting or international travel (Stebbins, 2008). The third form of leisure is serious leisure, in 
which people place significance upon their participation in a chosen leisure and derive durable personal and social rewards from their involvement (Stebbins, 1992).

Sociologists have applied serious leisure theory to several different activities to illustrate the benefits that participants achieve. The grounded theory of serious leisure, developed out of studies of amateurism by Robert Stebbins (1992), is defined as "the systematic pursuit of an amateur, hobbyist, or volunteer activity that is sufficiently substantial and interesting for a participant to find a career there in acquisition and expression of its special skills and knowledge" (p. 3). In his studies of amateur participation in theater, baseball, and archaeology, Stebbins (1992) found that highly dedicated individuals experienced self-fulfillment and social interaction through interesting leisure activities. Since then, the perspective of serious leisure has been applied to illustrate how activities demonstrated its characteristics. One such characteristic, perseverance, was evidenced in the leisure activity of shag dancing (Brown, 2007). Durable personal benefits realized from serious leisure participation have been evidenced in activities such as competitive dog showing (Baldwin and Norris, 1999) and bird watching (Lee and Scott, 2006). The unique ethos that develops around a serious leisure activity has been illustrated in studies of yachting (Aversa, 1990), gym membership (Gahwiler and Havitz, 1998), canoeing (Sharpe, 2005), snowboarding (Thorpe, 2005), windsurfing (Wheaton, 1998), and motorcycling (Austin and Gagne, 2008; Gagne and Austin, forthcoming; Maxwell, 1998). The element of identity formation that is attributed to serious leisure involvement has been examined among runners (Collinson and Hockey, 2007), soccer fans (Jones, 2000), and female boxers (Mennesson, 2000). Many of the activities that have been scrutinized in leisure studies 
can be classified in more than one theory of leisure. Studies of skydiving (Celsi, Rose, Leigh. 1993; Laurendeau, 2006; Laurendeau and Van Brunschot, 2006; Lipscombe, 1999; Price and Bundesen, 2005) are framed by serious leisure theory's concepts of commitment, unique ethos, and personal durable benefits, as well as the concepts of risk negotiation rooted in Lyng's theory of edgework (Lyng, 1990). This is also true of several risk-, action-, and skill-intensive leisure activities such as rock climbing (Llewellyn and Sanchez, 2008), surfing (Diehm and Armatas, 2004), and motorcycling (Roster, 2007).

\section{Leisure Motivation Concepts}

An important element that distinguishes leisure from work is that the individual engages in the activity is for its own sake and realizes intrinsic rewards. Leisure is not performed for compensation or rewards from others, but simply for the personal and social benefits that are experienced through the act (Waterman, 2005). This means that leisure is intrinsically motivated, because it satisfies one's basic needs of competence and autonomy (Deci and Ryan, 2000). The benefits of the leisure experience are directed toward the self, and the form of leisure chosen may satisfy desires ranging from relaxation to exhilaration. Many studies have applied the concept of intrinsic motivation to leisure. Studies have focused on how intrinsic motivation and leisure are affected by factors such as culture (Walker, Deng, and Dieser, 2005), the intersection of ethnicity and gender (Walker, 2008), and age (Van Hiel and Vansteenkiste, 2009).

This study of women who fly airplanes for pleasure examines the motivation for their engagement. Early studies of leisure motivation clearly indicated that intrinsic, rather than extrinsic, motivation is essential to the achievement of the leisure state of 
mind (Deci and Ryan, 1985). But the development of self-determination theory found that the leisure state of mind, which are positive emotions such as enjoyment and freedom (Shamir, 1992), can be realized through when extrinsic motivation is internalized and integrated (Ryan and Deci, 2000). Motivation, the force driving a person to take action, is a continuum in which intrinsic motivation is the higher point and amotivation is the absence of action (see figure 1). Intrinsic motivation is defined as "the inherent tendency to seek out novelty and challenges, to extend and exercise one's

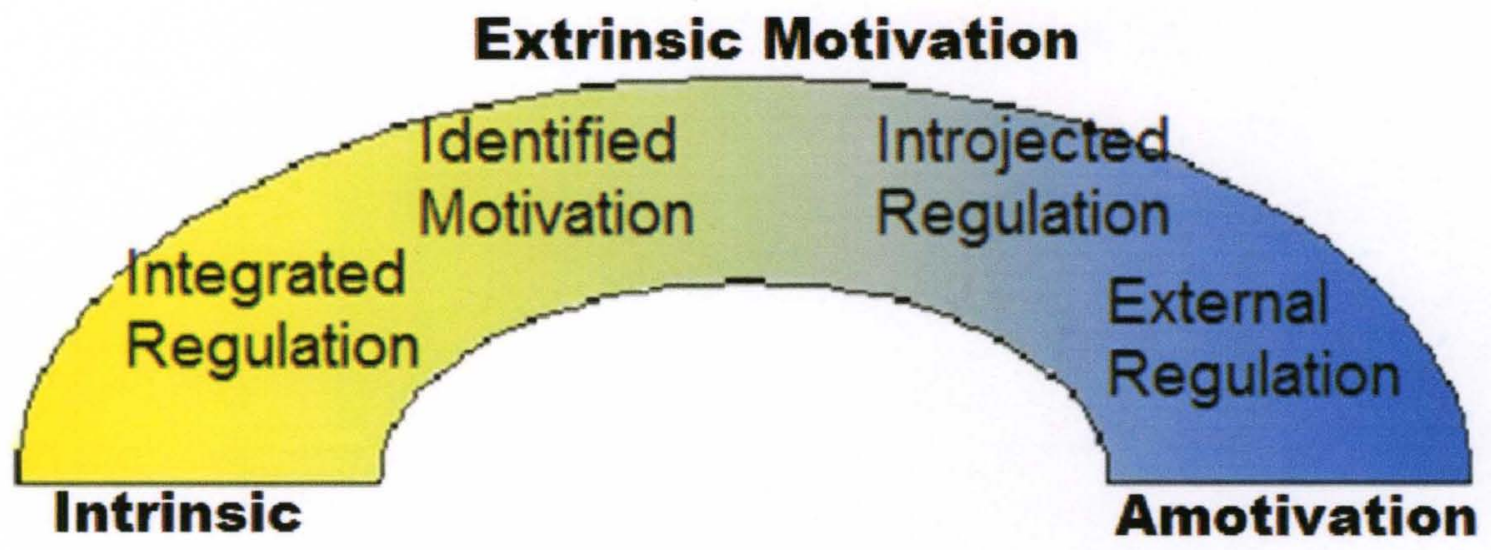

Figure 1: Motivation Continuum of Self-Determination Theory (Deci and Ryan, 1985) capacities, to explore, and to learn" (Ryan and Deci, 2000, p. 70). Between these two points are varying degrees of extrinsic motivation.

Extrinsic motivation involves engaging in an activity as a means to an end, an external reward, rather than for its own sake. Four levels of extrinsic motivation are identified which represents to the varying levels autonomy/external control. When action is taken solely with the expectations of external rewards there is least likelihood of deriving self-fulfillment. This level is referred to as external regulation. The next level is introjected regulation in which an individual is internally driven to achieve a sense of accomplishment or mastery or to fulfill a role or expectations of others. Self- 
actualization is not realized at this level, although they do experience pride from their involvement.

Points on the continuum that are closer to intrinsic motivation represent the states in which an individual agrees with the values and behaviors which are valued by others. These two degrees, identified motivation and integrated regulation, represents selfdetermination. When an individual agrees with the value of an action that is held by others and acts upon it, they are exhibiting identified motivation (Alexandris, Tsorbatzoudis, and Grouios, 2002). Integrated regulation occurs when an individual internalizes an externally motivation behavior and integrates the value of the behavior into their own sense of self. This internalization produces a sense of intrinsic motivation. So the individual thinks that their action is self-driven even though it is induced by the expectation of a positive external reward (Ryan and Deci, 2000). The external reward is then regarded as less of a motivation factor in the decision to take action. Integrated regulation has been linked to serious leisure participation (Walker and Wang, 2008). "Extrinsic motivation refers to the performance of an activity in order to attain some separable outcome and, thus, contrasts with intrinsic motivation, which refers to doing an activity for the inherent satisfaction of the activity itself" (Ryan and Deci, 2000, pg. 71). Studies have shown that intrinsically motivated action satisfies three innate psychological needs which contribute to personal development, social functioning and emotional well-being: competence, relatedness, and autonomy (Walker, Deng and Dieser, 2005). The concepts of intrinsic motivation and the various degrees of extrinsic motivation are useful in analyzing involvement in serious leisure (Carroll and Alexandris, 1997; Iso-Ahola and Park, 1996). This study looks at how benefits of serious leisure are 
affected by the motivation of participants. I expect that women who were intrinsically motivated would realize internal benefits of self-fulfillment and enjoyment as they engaged in leisure for its own sake. Women, who engaged in leisure for an external reward or for the sake of a significant relationship, would be expected to realize external benefits. When the participant felt that the activity was interesting enough to pursue but did not take action unless there was an incentive offered, I would expect internal benefits and external rewards to be present.

The concept of leisure as agency (Freysinger, 1995) is synonymous with the concept of intrinsic motivation as explained by self-determination theory (Deci and Ryan, 1985). The intended beneficiary of intrinsic rewards of leisure is the self. Leisure pursuits result from an individual's own interests and enthusiasm, often becoming one's passion (Stebbins, 1992). Intrinsically motivated participation requires no encouragement from others to pursue activities that will provide self-directed benefits. These benefits are realized through repeated engagement in the leisure activity. Leisure as agency demonstrates an individual engaging in an activity for its own sake (Kelly, 1983).

In leisure as affiliation, individuals pursue leisure activities without a genuine interest in the activity or a goal of achieving intrinsic rewards from their leisure involvement. The main purpose of leisure as affiliation is the pleasurable interaction with specific others, often family or friends (Freysinger, 1995). The focus of the benefits of affiliative leisure is outside of the individual. Other people are the targeted beneficiaries of pursuit of leisure as affiliation. This form of leisure is extrinsically motivated in that 
there is an expected reward of a positive contribution to the relationship between the leisure partners.

When individuals engage in shared leisure activities for the purpose of enriching the relationship with their spouse or partner, they are motivated to adopt behaviors that will result in an external reward. According to self-determination theory, "internalization" occurs when individuals integrate externally driven behaviors into their own sense of self, which leads to engaging in activities that they otherwise considered unappealing (Ryan and Deci, 2000). A study of midlife women's leisure found that many women did not think of marital or family leisure as their own leisure (Bialeschki and Michener, 1994). This study examines leisure motivation to find whether each woman's decision to pursue piloting as leisure was purely self-motivated or for the purpose of sharing in the leisure practice of another, specifically a spouse or partner.

Sharing in leisure activities with a significant other can have its advantages. Shared leisure of partners can increase enjoyment of leisure activity (Goff, Fick, and Oppliger, 1997), and satisfaction with the relationship (Kalmijn and Bernasco, 2001). Shared leisure activities among married couples increases "marital capital," a combination of investments in the relationship that serve to strengthen their attachment and reduce the chance of divorce (Hill, 1988; Kalmijn and Bernasco, 2001). Marital capital in the form of compatibility of interest and quality of time spent together has little value if the marriage were to dissolve (Hill, 1988). On the other hand, shared leisure may lead to losing individualism, developing too much dependence on the spouse, and encountering time constraints from conflicting schedules (Kalmijn and Bernasco, 2001). 
In a study of companionate leisure, it was found that marriage satisfaction is higher when both spouses equally enjoy interest in the activity (Zabriskie, Johnson, and Hill, 2006).

Among research on shared family leisure, mutually-held attitudes of shared leisure by couples contribute to marital longevity (Siegenthaler and O'Dell, 2000). Several studies affirm that the sharing of salient leisure activities by couples contributes to the quality of the relationship (Baldwin, Ellis and Baldwin, 1999; Hill, 1988; IsoAhola, 1980). However, wives experienced lower marriage satisfaction from participating in shared leisure in which they had less interest than their husbands (Crawford, Houts, Huston, and George, 2002). Studies have shown that the time spent in shared leisure does not contribute to marital satisfaction when leisure interests are incongruent (Johnson, Zabriskie, and Hill, 2006). Another study has indicated that even sharing in activities that the couple agrees upon does not always provide (Berg, Trost, Schneider, and Allison, 2001).

Leisure allows the opportunity to discover and cultivate a new identity that cannot be found in other areas of life. Leisure allows people to have experiences and develop relationships that are outside of their everyday routines (Lee and Scott, 2006).

Engagement in a leisure based community contributes to the development of one's social self and social identity (Arai and Pedlar, 2003). Female-only leisure space is more likely to allow a woman to find empowerment through a leisure activity-based identity, and develop her social self through relationships with others (Gagne and Austin, forthcoming; Green, 1998). Gendered identity construction is a recognizable benefit that comes from social interactions within leisure activity-based communities. Traditional feminine (Wearing, 1995) and masculine (Hunt, 2008) identities can be created, re-created, 
challenged, or confirmed through the social relationships that surround serious leisure activities. The study of women's involvement in serious leisure has not examined whether companionate leisure and self-motivated leisure result in consistent benefits. This study intends to fill this gap by examining the personal and social benefits realized by those self-motivated to engage in airplane piloting as leisure as agency compared to those motivated to share in airplane piloting as leisure with a significant other, thus performing leisure as affiliation. 


\section{CHAPTER III}

\section{RESEARCH METHODOLOGY}

This study seeks to contribute to a greater understanding of the phenomenon of leisure through the application of grounded theory methodology (Glaser and Strauss, 1967) by the examination of women actively involved in airplane piloting as serious leisure. I recruited participants in this study by attending national piloting events. Numerous regional and international piloting events attract professional and nonprofessional pilots. In order to study women's participation in recreational airplane piloting, I attended an annual conference of an exclusively women pilot organization, the Ninety-Nines (99s) held in Chicago, Illinois during July 23-26, 2009. From Chicago, I then traveled with members of the 99 s to Oshkosh, Wisconsin, where I attended a weeklong annual aviation event sponsored by the Experimental Aircraft Association (EAA) held during July 27 to August 2, 2009, which participants commonly referred to simply as "Oshkosh." I chose to adopt a peripheral-member-researcher role while conducting field research at these two piloting events.

According to Adler and Adler (1987), researching a group in a peripheral role does not involve participation or commitment to the group being observed. In this capacity, I was able to meet several female pilots and have casual conversations with them about their involvement in piloting as a leisure activity. It provided me an opportunity to solicit volunteers for this study as well as to gain helpful information about 
piloting and being a peripheral member of the community of pilots. Due to time limitations, it was impractical to conduct formal interviews during these events. Instead I shared information about the study, obtained contact information, and collected signed informed consent forms from volunteer participants. Afterwards, I recorded accounts of the casual conversations in my field notes, in an established field research method (Arksey and Knight, 1999).

During field research in Chicago and Oshkosh, I spoke to many women about airplane piloting and was able to gain insight into their experiences and what flying means to them. Participant observation in the field allowed me to witness the social interaction of members of this social world. Experiencing the social environment that surrounds a leisure-based activity is important in understanding the meanings and experiences of the activity's participants (Denzin, 1970). Through these casual conversations with dozens of women, I found that many of them had been active in piloting for several decades, and that the draw to the activity varied considerably. This deeper understanding enabled me to sharpen the focus of my interview guide.

Interview guides are used to provide a degree of structure in the interview process (Patton, 1987). In accordance with grounded theory procedures, analysis begins when data collection begins (Corbin and Strauss, 1990). I analyzed each bit of information as I obtained it to enrich the research process. While in the field, I recruited 30 volunteers who were willing to be interviewed at a later date about their free-time involvement in airplane piloting. They all provided contact information and signed informed consent forms. 
The next step involved follow-up with the women. I developed an initial openended online questionnaire sent as a link to all volunteers who had provided e-mail contact information. The use of online questionnaires for both quantitative and qualitative research has been found to provide substantially more advantages than disadvantages to the research process (Garcia, Standlee, Bechkoff, and Cui, 2009; Murthy, 2008). The intent of this questionnaire was to ascertain that each participant met the criteria of the study, in that they 1) held a pilot certificate; 2) participated in piloting as a leisure activity, rather than a profession; and 3) had been a pilot for 15 or more years. The questionnaire also allowed the gathering of basic demographic information and preliminary data on piloting involvement. It gave each volunteer an opportunity to give detailed contact information, such as best times to be reached for a telephone interview, or if she preferred the interview process be conducted through e-mail. Several women I had spoken to during my field research indicated interviewing by e-mail would serve their schedules better. A study of computer-mediated communication in qualitative research reported a growing trend towards using e-mail to conduct in-depth interviews (Garcia, Standlee, Bechkoff, and Cui, 2009).

Several respondents forwarded the questionnaire link to other female pilots resulting in a snowball sampling technique. Snowball sampling is the result in which the initial members of the purposive sample recommended other people to contribute to the study (Patton, 1990). A total of 28 emails were sent to women who had volunteered for the study during my field research. Two volunteers had provided only telephone numbers for contact information. Of the 28 volunteers, only 19 responded by completing the on-line questionnaire. Yet within three weeks, additional responses from women 
referred to the study resulted in a total of 60 completed questionnaires. Career and student pilots, along with non-pilots, were outside of the focus of this study, so they were excluded from the sample pool. Ten of the women participating in this study were recruited during the field research at the events through convenience sampling and six were referred through snowball sampling.

To further refine the purposive sampling via in the interview scheduling process, this study prioritized women with at least 15 years of active involvement in airplane piloting as a leisure activity. I e-mailed informed consent forms and details about the study to the snowball sampling recruited participants. The signed consent forms were returned to me by fax, mail, or as e-mail attachments.

Data Collection

The interview process took place from August 2009 through February 2010. I prepared an initial draft interview guide and revised it as I found relevant information throughout the research process. This follows the tenets of grounded theory research methods (Strauss and Corbin, 1994). I used feminist research methodology in the interview process. Feminist research methodology and epistemology looks to women as the source of knowledge. This knowledge comes from the subjective meanings given by women to their own lived experiences. It is only possible to generate authentic knowledge of women's lives by centering women in the research process (Hesse-Biber and Leavy, 2007).

I conducted in-depth, semi-structured interviews with six participants by telephone, since they had indicated this as their preferred method of communication. The telephone interviews typically lasted one hour. I also conducted in-depth, semi-structured 
e-mail interviews with nine participants, which consisted of a series of e-mail exchanges with each respondent. There are advantages to conducting interviews by e-mail compared to telephone interviews, besides alleviating the task of transcribing of the interview (Murthy, 2008). E-mail interviewing is especially beneficial for research utilizing grounded theory. According to the principle of grounded theory (Glaser and Strauss, 1967; Strauss and Corbin, 1994), a researcher engages in constant comparison and analysis of data throughout the interview process. As patterns and relevant themes emerged, I was able to restructure my interview guide.

The interviews that were conducted by e-mail were actually a series of e-mails in which only a few questions were asked at a time. This allowed the follow-up questions to be added to focus on prominent themes and subthemes that emerged from other ongoing e-mail and completed telephone interviews. Although the use of e-mail for conducting interviews did result in a loss of personal contact, this did not lessen the quality of data gathered. Instead, it allowed interviewees additional time to reflect upon their experiences, and to provide thorough and focused responses (Murthy, 2008).

I was prepared to adjust the criteria of the sample by including women with 10 years of piloting involvement, if it was necessary to achieve data saturation. Grounded theory methodology calls for including new participants into the study until no new information is being discovered (Bowen, 2008). I reached theoretical saturation (Glaser and Strauss, 1967) after completing interviews with 16 women who all had experience over 15 years in amateur airplane piloting. Theoretical saturation is the point at which performing additional interviews will not bring about new data, but simply corroborate themes already discovered (Bowen, 2008). Of the 16 interviews conducted, 10 were e- 
mail interviews and six were telephone interviews. I digitally recorded telephone interviews to enhance the validity of the data (Arksey and Knight, 1999). I then downloaded the recordings into a computer and later transcribed all interviews.

There were differences noted in the interviews conducted by e-mail with those by telephone. I found that the responses were more direct and focused within e-mail interviews and it was difficult to probe for a deeper understanding. Often follow-up questions would yield either no response or repetition of responses already provided. This was not a problem in telephone interviews. In telephone interviews, I felt a stronger, more personal connection to the participants than I was able to achieve in the e-mail interview format. I was able to respond better to the tone of the responses and instantly follow-up and probe as necessary. I found much richer descriptions emerging from telephone interviews than from e-mail interviews.

\section{Data Analysis}

By choosing to use qualitative research, I was able to explore subjective meanings that female pilots gave to their participation in this form of leisure. In the process of discovering information to uncover the underlying motivations, processes, and benefits of engaging in this serious leisure, I followed grounded theory procedures by constantly analyzing what emerged from observations, conversations, and interviews. I used established methods of analytic induction in analyzing my field notes and interview transcripts (Charmaz, 1983; Huberman and Miles, 1994; Strauss and Corbin, 1994). I read through the transcripts of the recorded telephone interviews and e-mail interviews repeatedly during the on-going research period. Once I had reached theoretical saturation and had completed transcriptions of the final interviews, I closely examined each 
respondent's interview data for salient themes. The first step of formal data analysis entailed open coding (Strauss and Corbin, 1994). This step involved reading each line of interview data to find similarities and differences among repeated concepts. I coded all statements throughout the transcripts that reflected emerging concepts. Following grounded theory principles, I then grouped these concepts into categories. Identifying categories leads to developing theory (Corbin and Strauss, 1990).

Throughout the coding process, I recorded my analysis of the processes and meanings that emerged from the data which led to formulating the categories that developed during this study. A great deal of information came forth from the interviews, yet I limited the focus of this report to a core category with a limited number of subcategories. This would be described as the process of selective coding, which occurs during latter stages of analysis as a core category is defined (Corbin and Strauss, 1990). Analyses of the categories led to formulation of a model of long-term involvement in serious leisure.

Participants

The women interviewed for this study ranged in ages from 45 - to 85 -years old. At the time I interviewed them, all women had earned their private pilot certificate and had been involved in airplane flying as a leisure activity for at least 15 years. Four of the participants had been flying less than 20 years, and six of the women had flown for more than 30 years. With respect to relationship status, 11 were married or partnered. One woman was single, two were widowed and two were divorced. With respect to education, all but one held college degrees. Eight women held either 2-year or 4-year 
college degrees. Seven women held advanced degrees, three at the master's and four at doctorate level.

All participants in the sample were white, except one Native American woman. The majority of respondents who provided information reported their annual household incomes were in excess of $\$ 100,000$ per year. All participants identified as middle class or upper middle class. Other characteristics of the participants are provided in Table 1. I used pseudonyms in place of participants' given names to ensure confidentiality. I have securely maintained all printed and electronic transcripts of interviews and e-mail correspondence. 


\section{Table 1}

Characteristics of Participants $(\mathrm{N}=16)$

\begin{tabular}{|c|c|c|}
\hline Characteristics & & Frequency \\
\hline Age: & $\begin{array}{l}\text { Under } 39 \\
40-49 \\
50-59 \\
60-69 \\
70-79 \\
80-89\end{array}$ & $\begin{array}{l}0 \\
1 \\
5 \\
4 \\
5 \\
1\end{array}$ \\
\hline Years of Airplane Piloting & $\begin{array}{l}15-19 \\
20-24 \\
25-29 \\
30-34 \\
35-39 \\
40-44 \\
45-49 \\
50+\end{array}$ & $\begin{array}{l}3 \\
5 \\
2 \\
3 \\
0 \\
1 \\
1 \\
1\end{array}$ \\
\hline Relationship status & $\begin{array}{l}\text { Single } \\
\text { Divorced } \\
\text { Widowed } \\
\text { Partnered } \\
\text { Married }\end{array}$ & $\begin{array}{c}1 \\
2 \\
2 \\
1 \\
10\end{array}$ \\
\hline Number of Children & $\begin{array}{l}\text { None } \\
1-3 \\
4+\end{array}$ & $\begin{array}{l}6 \\
7 \\
3\end{array}$ \\
\hline College degree earned & $\begin{array}{l}\text { None } \\
\text { Associate } \\
\text { Bachelor's } \\
\text { Master's } \\
\text { Doctoral }\end{array}$ & $\begin{array}{l}1 \\
3 \\
5 \\
3 \\
4\end{array}$ \\
\hline
\end{tabular}




\section{CHAPTER IV}

\section{FINDINGS}

This study contributes to the literature of serious leisure with its findings that showed a variance in the motivation of the pursuit of amateur airplane piloting among women private pilots. I identified three patterns of motives of serious leisure pursuit from the interview data which contribute to the understanding of women involvement in male-dominated, skill-intensive and high-investment serious leisure activities. To situate these findings within the social context and facilitate greater understanding, it is necessary to first address some of the Federal Aviation administration's (FAA) regulations for private pilots and to explain briefly the history of women in flight. In the next section, findings from the interview data demonstrate that airplane piloting fulfills the six qualities of serious leisure (Stebbins, 1992). As the women of this study shared their experiences of engaging in a male-dominated serious leisure activity, I found that they were drawn to piloting for several different reasons. I identified three categories of women pilots based upon their various motives. I identified one group of women as independent pilots who pursued piloting as a self-oriented leisure pursuit. I found a second group of women who pursued piloting for the initial purpose of engaging in companionate leisure. I designated this group as dependent pilots because their initial interest in airplane piloting was linked to their significant other's involvement in flying. I 
identified a third category of women pilots, interdependent pilots, who decided in concert with their significant others to pursue piloting as a shared leisure activity.

This study provides an opportunity to learn about women's participation in a unique serious leisure activity. Piloting requires a significant amount of time, effort, and money to develop and maintain specialized skills and knowledge. Airplane expenses are considerable. Piloting small airplanes is often perceived as a high-risk activity. The combination of these factors makes this study of women pilots an opportunity to shed insight upon women's involvement in skill-intensive, cost-prohibitive, high risk serious leisure. In addition to examining the motives of pursuit of a unique serious leisure, this study examines the benefits realized by women's engagement. From the interview data, I found accounts which demonstrated the personal and social benefits realized by each category of pilots and looked for consistency between the three categories. Findings that indicate inconsistencies of benefits lead to the notion that the experiences of serious leisure are affected by the motivation of pursuit. Therefore, it leads to a conclusion that a greater understanding of serious leisure can be facilitated by a categorization of participants' motivation.

\section{Women in General Aviation}

To become a private pilot in the United States, a person must pass a medical examination and complete a minimum of 40 hours of flight instruction before being tested by the Federal Aviation Administration (FAA, 2010). A private pilot certificate entitles an individual to fly for personal business or pleasure. Further licensing is required to be employed as a pilot. At of the end of 2009, the FAA estimated that there were 211,619 active private pilots in the United States and over 93 percent of them were 
men (FAA, 2010). Women have consistently and historically represented a minority position in aviation. For example, except for the short-lived Women Airforce Service Pilots (WASP) program during World War II, the United States Air Force (USAF) did not allow women into pilot training until 1976 and into fighter pilot training until 1993. After nearly a century of the military training aviators, as of 2010 women accounted for only 4.4 percent of the pilots in the USAF (Air Force Personnel Center, 2010). In civil aviation, women account for less than 7 percent of non-professional pilots and approximately 5 percent of professional pilots (FAA, 2010). All participants in this study held private pilot certificates and flew for leisure. Several women held advanced aviation ratings and certificates. The sample included women who were certified flight instructors, but not career commercial or airline pilots.

\section{Airplane Piloting as a Serious Leisure}

This study contributes to the literature of serious leisure by examining the participation of women who pilot airplanes for pleasure. According to Stebbins (1992), participants in a serious leisure activity are referred to as hobbyists. If there is a professional counterpart, participants are referred to as amateurs. The use of the term amateur is appropriate for sociological analysis, yet participants in this study referred to airplane piloting as their hobby or recreation. In this study, these terms are used interchangeably. There are six qualities that identify a recreational pursuit as serious leisure: perseverance, leisure career, significant effort, durable benefits, unique ethos and identify formation (Stebbins, 1992). I found that all of these characteristics experienced in piloting airplanes for recreation. 


\section{Perseverance}

The quality of perseverance is conceptualized as "persistence in a goal-directed behavior over time" (Gould, Moore, McGuire, and Stebbins, 2008, p. 49). Most of the women in the study were adults when they decided to become airplane pilots and earned their certificates within two years of their initial interest. However, many of the women in this study became interested in aviation as young girls or teenagers. This dream of becoming a pilot was typically sparked by an adult male relative involved in aviation. I found that women who had held an interest in becoming pilots as minors were most likely wait until they reached a point in their lives in which they had the time and/or the money needed to dedicate to pursuing flying as a leisure activity. In some cases, these were dreams that took over 30 years to realize. For instance, since her teens, Paula had harbored a secret ambition of becoming a pilot. She felt that it was just too far out of the realm of possibility until she met the man who would later become her second husband. She was unaware that he was already a pilot when she shared with him her dream of flying. With his encouragement, she began taking flight lessons. "Learning to fly was my first goal," Paula, 68, said, "and I really had no clue what it would take to get to go all the way through the license." It took her eight years and three different flight instructors, but she persisted and earned her private pilot certificate at the age of 38 .

\section{Leisure career}

All of the women in this study had high levels of interest in and long-term commitment to airplane piloting. This demonstrates the concept of leisure career, the second quality of serious leisure (Stebbins, 2007). A study of adult amateur ice skaters demonstrated that participants in a serious leisure career need to strive to maintain 
satisfying experiences from enduring involvement (McQuarrie and Jackson, 1996).

Evidence of the leisure career, is seen when Alice, 70, said "the first few months of flying are so exhilarating, that it must continue!" These continuous searches for the previously experienced rewards are what frames a serious leisure career (Stebbins, 2007).

\section{Significant effort}

The third quality of serious leisure pertains to the challenge of being able to perform an activity that requires special knowledge, skills, and abilities (Stebbins, 2007). A significant degree of time, expense, and personal effort is needed to become an airplane pilot. All respondents in this study completed the requirements to earn their private pilot certificates, and several earned advanced ratings and certificates. Many felt that becoming a pilot was a major accomplishment.

Flying certainly provides an incredible satisfaction for the person - it is such a tremendous accomplishment and I marvel each time I fly. (Alice, 70 , began flying at age 50)

My whole world changed when I learned to fly; the self satisfaction that I could accomplish this. I am proud I did it and have never regretted any part of this exhilarating experience. (Wanda, 76, became a pilot at age 31)

Setting and achieving the goal of becoming a pilot is probably one of the larger challenges I have conquered in my lifetime, the benefit to my psyche is immeasurable. (Sheila, 59, a pilot since age 35)

\section{Durable benefits}

The fourth quality of serious leisure, durable benefits, is quite the opposite of casual leisure's positive outcomes of pure pleasure, or hedonism (Stebbins, 2001). These enduring agreeable outcomes can be in the form of personal benefits, which contribute to the self or social benefits, which contribute to interactions with groups and others. Durable benefits from engaging in serious leisure are often unanticipated. "The 
empowerment and self-esteem is overwhelming," said Dana, 65. "It just enables you to achieve much more than you had ever dreamed of."

\section{Unique ethos}

Participants in a serious leisure activity share distinctive attitudes, values, and beliefs that serve to bond them as a group (Stebbins, 1992). This fifth quality of serious leisure, unique ethos, enables an activity-based social world (Unruh, 1979) that focuses primarily on the specific activity. As in the aviation community, professionals, and amateurs form strong bonds with others who share in the activity of airplane piloting. Sheila, 59 , described being a member of the $99 \mathrm{~s}$, an exclusive international pilots organization open only to licensed female pilots:

It is wonderful to have access to so many other women who are of like mind. We are all much more self confident, adventuresome and willing to explore different opportunities than the average woman. We have all conquered the complexities of learning to fly which has helped us to feel comfortable about trying other new things and exploring new places both together as a group and as individuals.

\section{Identify formation}

Participants exhibit their identification with a serious leisure activity (Stebbins, 1992). This sixth quality of serious leisure enables a person to find a new identity through their leisure pursuit. Pilots share a common sense of experience and meaning in the flying which become a part of their self-identity. "It [flying] has to be an integral part of your life," said Nancy, 67; "the rigor and discipline it demands spill over into other aspects of your life, with positive results."

While serious leisure conceptualizes important difference between those for whom leisure has become a career and those who approach it more casually, it does little to promote understandings of what motivates people to engage in piloting as a form of 
serious leisure. Findings of the various ways in which women become involved in piloting as serious leisure demonstrated that three basic categories exist: the independent pilots, the dependent pilots, and the interdependent pilots.

\section{Motivations to Become Airplane Pilots}

All women in this study, except one, indicated that their aim in becoming a pilot was to engage in it as a recreational or leisure activity. The one exception, Sheila, 53, considered a career in aviation while in training, but later decided against it:

I became a pilot about 25 years ago... I thought I would like to give flying a try, and if I liked it enough was going to pursue a career in aviation... nailed my private pilot license in 41 hours, went on to fulfill all the practical requirements for commercial and instrument ratings, aced the written exams, and needed only a check ride when my father passed [away]. At that point I stopped flying for a while and never revisited it with an eye to flying as a vocation, although I still fly recreationally to this day.

Some of the women in this study said that they had wanted to become pilots since they were young girls. Interest at a young age was typically due to exposure to aviation through male relatives or family friends. Some women developed an interest in aviation as teenagers, but were constrained from pursuing their license until later as adults. While in high school during World War II, Vera, 85 , became inspired to become a pilot:

I was 16 or 17. I lived in Southern California at the time and was still in high school when World War II started and everyone was going off to jobs in the defense industry. I heard about the WASPs and thought that sounded fascinating, but I had never been in an airplane and am terrified of heights so didn't think I would even like it. Got someone to drive me... to take a flight ... Just loved the flight! I ... did not have any money, so was not able to learn to fly to qualify for the WASPS. It closed before I was old enough.

Other women became interested in becoming pilots as adults. This interest was typically sparked by exposure to airplane piloting as recreation through a friend or 
acquaintance already involved in flying or flying lessons.

A friend was working on his pilot license and I thought I'd give it a try. Once I got in the air for my initial introductory less, I was 'hooked'. (Alice, 70, started flying at age 50)

In graduate school, a retired air force pilot/student in one of my classes introduced me to it, and took me to a local flight school. I caught the fever on my first demo ride and fell in love with flying. (Claire, 45, a pilot since age 25)

Often opportunities to fly in small airplanes led to decisions to pursue piloting.

After a small plane flight with friends, I invited my husband to get his license, and he said that he was busy building his business, that I should do it... so I did it. (Tina, 70, a pilot for 43 years)

Some of the women in this study were in significant relationships with airplane pilots when they decided to get their pilot certificate.

I more or less decided that if he was going to be flying that if I was going to fly with him that I would like to know what was going on. (Gloria, 79, a pilot since age 4I)

I found that several women and their partners engaged in airplane piloting as a shared leisure activity in which they both began training at or near the same time. These situations were a result of experiencing small airplane flying or as an unexpected suggestion by one of the partners. For instance, Betty, 52, decided to become a pilot after her husband suggested it to her.

My husband was interested in building a plane and suggested I learn to fly. He was a private pilot but was not currently flying. I never flew with him at all. I went to take the ground school then flying lessons and loved it!

These findings illustrated that the circumstances leading women to become involved in airplane piloting varied among the participants of this study. The duration of time between the initial idea of pursuing piloting and enrolling in flight training ranged from a day to 30 years. 


\section{Categories of Women Pilots}

\section{Independent Pilots}

I found in this study that some women exhibited signs of being intrinsically motivated to become airplane pilots, while others did not. According to Deci and Ryan (1985), intrinsically motivated actions are generated from the expectation of enjoyment in engaging in activities for their own sake. Intrinsically motivated leisure behavior satisfies the individuals' needs for competence, relatedness, and autonomy (Deci and Ryan, 1985). Women demonstrated intrinsic motivation through comments such as:

It is my outlet, something I do just for myself. (Alice, age 70)

I became a pilot because I wanted to since I was 6. (Kelly, age 59)

I caught the fever on my first demo ride and fell in love with flying. (Claire, age 45)

I had always harbored a wish to fly. I was living and working in West Africa and the CFA franc was devalued. That suddenly made it affordable for someone paid in US Dollars to learn to fly. So I did. (Nancy, age 67)

I cannot imagine not being able to fly. (Vera, age 85)

My motivation was that when very young I was exposed to general aviation, found it to be exhilarating and swore to myself that one day I would become a pilot. (Sheila, age 53)

These women who expressed being intrinsically motivated were self-motivated to take action to become airplane pilots. Their decision to initiate flight training was made as a direct result of their interest in the activity itself. These women pilots performed leisure as agency (Freysinger, 1995) in which the desired outcomes from engagement were directed inwardly toward the self, as opposed to outwardly toward others. These desired outcomes were derived directly from the activity itself, rather than from an external source. They were under no obligation to others to pursue piloting as leisure. 
They found it self-rewarding and self-fulfilling enough to justify the efforts and sacrifices that may be necessary to pilot airplanes. I categorized this group of women as independent pilots. Independent pilots described their excitement of flying with terms such as their passion, being hooked, and love of flying. Most of the women who were identified as independent pilots did not personally know any other women pilots when they began flying lessons.

\section{Interdependent Pilots}

I found that even though a woman may have developed an interest in aviation at an early age, an extra incentive to take action may be necessary. Although Dana wanted to become a pilot since her early 20 s, her decision to begin lessons at the age of 41 was brought about by a relationship with a pilot.

However my boyfriend is a pilot so that did affect me on some level. We fly a lot together and go to a lot of flying activities. So in a way it keeps us together. When he can't fly I do the flying and when I can't he will pick up the slack.

Dana held a genuine interest in becoming pilots, but she did not take action to realize her goal independently. Instead her motivation was based upon the influence and support offered by a significant other. She, along with other women in this study, engaged in mutually-determined shared leisure which represents integrated regulation (see Figure 2), a low degree of extrinsic motivation situated next to intrinsic motivation in the motivation continuum (Ryan and Deci, 2000). Their motivation was internalized and integrated to produce a sense of intrinsic motivation, although an external reward is expected. According to self-determination theory's concept of internalization, behavior that is not compelling enough to provoke action without an expectation of an external reward is extrinsically motivated behavior. Studies show that people adopt, or internalize, 
behaviors that are valued by their significant others out of a need to feel connectedness and strengthen the significant relationship (Ryan and Deci, 2000). As individuals integrate the external value into their own sense of self, self determination occurs. This gives the individuals a sense that the resulting action is one that comes from the self, rather than from others. This level of extrinsic motivation results in intrinsic rewards as well as the expected external reward. I categorized this group as interdependent pilots.

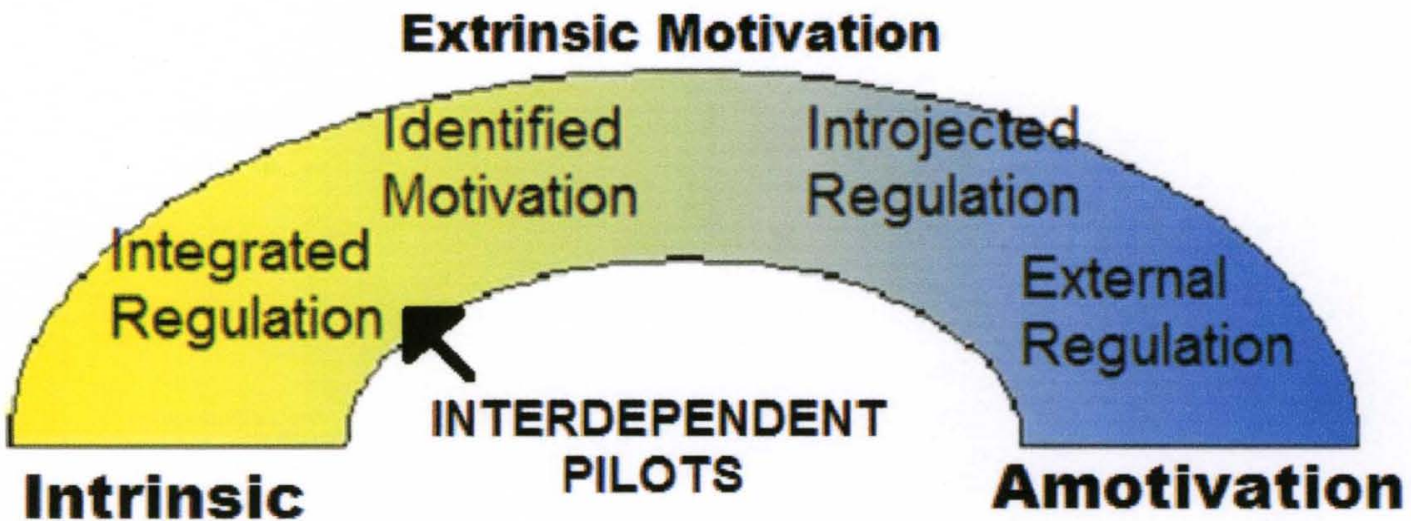

Figure 2: Motivation Continuum indicating location of interdependent pilots' motivation.

Many of these women suggested airplane piloting to their significant others as a hobby to share together. They found flying as an appealing activity, but their selfmotivation was not strong enough to move them to action on their own. The addition of an extrinsic reward did push them towards action. In most cases, the reward was relationship-based with both partners deciding at or near the same time to engage in piloting.

I found that involvement in airplane piloting as shared leisure contributed to their significant relationships, which indicated leisure as affiliation (Freysinger, 1985) in that their actions were directed towards others rather than self. When one was motivated to 
achieve a desired outcome that was focused on a specific other, such as a spouse, the enrichment of the targeted relationship was the desired external reward.

Such cases involved married couples who decided to pursue piloting at or near the same time. After Wanda, 76, and her husband took a small plane flight during a vacation in Alaska in 1962, during which they realized that they were missing too much scenery on the ground, she suggested that they pursue flying as a shared leisure activity. Elaine, 59 , suggested to her husband that he become a pilot:

So my husband and I were sitting at breakfast one morning and talking about whether we would move with my job or not, and where it might go. I said, "I think they're going to move us ... why don't we move. And we'll get a cabin back in Minnesota, and you can learn to fly an airplane and we can come back to Minnesota on weekends to our cabin." And I didn't realize that he had wanted to learn to fly all his life. So it took an extremely small amount of arm twisting for us to leave breakfast, go down to the airport and sign him up for flying lessons.

At the time of the suggestion, Elaine had no interest in also becoming a pilot. But she realized that flying was not just transportation but a hobby that she enjoyed. She pursued flying lessons along with her husband.

We learned about flying together, we quizzed each other on the aviation alphabet when we were driving, to help each other remember it. I would always do nasty things to him by throwing the circuit breaker of the landing gear during a practice approach to see if he noticed. He never could sneak enough to do that to me, he tried. We did things to keep each other sharp that were safe. They were the type of things a flight instructor would do.

In addition to piloting airplanes as a shared leisure activity, all of interdependent pilots often flew alone or with other pilots beside their significant others. Wanda and her husband began flying lessons in 1964 and shared piloting until his death in 2008. She continues to fly alone and with other pilots. Elaine and her husband began flying at the same time, and continued for 25 years until their divorce. Elaine stopped flying once the 
airplane was sold. A factor I found among interdependent pilots was that a woman's participation in flying can endure longer than the relationship that contributed to her initial involvement. This finding demonstrated that some interdependent pilots continue to fly after the initial external reward is no longer present. This indicates a shift in motivation occurs during the life course as a woman's drive to continue flying is for intrinsic rewards after the external reward is removed.

\section{Dependent Pilots}

According to self-determination theory, action that is not motivated intrinsically falls within a continuum of extrinsic motivation (Ryan and Deci, 2000). Extrinsic motivation involves the expectation of tangible or intangible external rewards resulting from action. The external rewards that were found among most extrinsically motivated women to pilot as leisure were intangible in nature, mainly focused on their significant relationships. I categorized women who were motivated to become pilots solely for the purpose of flying with their significant others as dependent pilots. Dependent pilots were extrinsically motivated at the level of introjected regulation (see Figure 3). At this level of extrinsic motivation an internal drive compels one to achieve a sense of accomplishment or mastery, but participation is in response to fulfilling a role or expectations of others.

All of the dependent pilots in this study relied upon the encouragement and support of men in their initial involvement in airplane piloting. This usually involved a woman who flew with her husband as a passenger in his airplane for a while before deciding to become a pilot herself or deciding to become a pilot at the same time as a 




Figure 3: Motivation Continuum indicating location of dependent pilots' motivation.

significant other. These women did not hold an interest in piloting, but instead held an interest in the relationship with their partners. Aviation was the interest of these women's partners, and the women's pursuit of piloting depended upon their partners' involvement. These women engaged in aviation as companionate leisure (Crawford, Houts, Huston and George, 2002). They were driven mostly for the benefits to the relationship with another, or as a helper to benefit another, rather than for self-directed benefits. This situation supports the concept of leisure as other (Freysinger, 1995) in which the benefit is targeted towards a relationship with a specific other.

Some of the women had flown when their husbands piloted their own planes, and they decided that it would be a good idea to learn how to fly. Two of the women considered obtaining pinch hitter training which trains non-pilots to safely operate an airplane in the event of a pilot becoming incapacitated while flying. Both of the women decided instead to pursue private pilot certificates. "I more or less decided that if he was going to be flying that if I was going to fly with him that I would like to know what was going on," said Gloria, 79. Likewise, Rachel, 78, explained, "I figured if I was ever 
going to spend time with him, maybe I ought to get a license too." They said that they would have never obtained pilot certification otherwise. Likewise, Lois, 56, had no interest in becoming a pilot until her boyfriend started flying lessons:

I became a pilot because the man who I was dating, later became my husband, was learning how to fly and ... I was not getting in that little airplane and not know how to fly it. I figured if it was his turn to go, it did not need to be mine. My main reason to learn to fly was self preservation.

My categorization of women's participation in serious leisure as independent, interdependent, or dependent emerged from the data of this study. Although selfdetermination theory's concepts of intrinsic and extrinsic motivations were found within the accounts of women becoming pilots, these concepts were not definitively linked to one category or another. Women who engaged in independent piloting did exhibit intrinsic motivation, and most women engaged in dependent piloting exhibited extrinsic motivation. However, signs of both intrinsic and extrinsic motivations were detected among women engaged in interdependent piloting. This method of categorizing women's participation has the potential to aid in the understanding of women entering into male-dominated leisure space. The next section examines the personal and social benefits derived by women from participation in airplane piloting as a serious leisure, followed by a comparison of benefits realized by independent, interdependent and dependent pilots.

\section{Personal and Social Benefits of Amateur Airplane Piloting}

I asked about the benefits of flying both directly and indirectly. I asked "What are the personal and social benefits you have realized from piloting airplanes?" I also asked many of the women what benefits they found from being a member of the $99 \mathrm{~s}$ womenonly piloting organization. I also looked for benefits from the responses to four of the 
questions that asked them to describe the meaning they held of piloting, the function that piloting provides for them, how they feel when piloting, and what was the lure of flying that they experienced when they first piloted.

Another indirect way of finding the benefits of airplane piloting was to ask "What do you feel is different about the women who do become pilots from those who don't?" I then turned it around from the general to the specific by asking, "Do you realize something about yourself that led you to become a pilot that may be uncommon among the majority of women who do not fly?" The responses to these questions brought out characteristics that women see as distinctive of women who pilot airplanes and women who don't. I also found benefits in the responses to the questions concerning the significance of piloting, passion for piloting, and involvement in the piloting organizations, specifically the $99 \mathrm{~s}$.

I found evidence of women deriving durable personal and social benefits from their participation in airplane piloting that were consistent with those identified in serious leisure theory by Stebbins (2007). The durable benefits outlined in serious leisure theory are: self-actualization, self-enrichment, self-expression, heightened sense of self, sense of accomplishment, improved self-image, sense of belonging and social interaction, financial return, and sense of enjoyment and fulfillment. I found all of these benefits unanimously among the respondents, with the exception of financial return. Financial returns were realized by many women who entered into aviation related activities that provide compensation or other financial rewards. Financial returns were realized by the two women in this study who became certified flight instructors, a woman who found her career as an air traffic controller through her flight school while taking lessons, a woman 
who reinvented herself into an aviator writer and several women who participated in air races, which provide monetary awards to the winners. Also, several women in the study had received scholarships and awards from piloting organizations such as the NinetyNines and Women in Aviation.

Similarly, self-determination theorists, Deci and Ryan (2000) identified three innate needs satisfied through optimal human functioning: competency, relatedness and autonomy. It was found in comparisons of actions which are intrinsically motivated and actions motivated by external rewards, benefits are typically experienced at a different level. Intrinsically motivated persons report having more interest, excitement, confidence, persistence, vitality, self-esteem, and general well-being than those motivated by external rewards (Ryan and Deci, 2000).

It has also been found that benefits vary when practicing leisure as affiliation or leisure as agency. Leisure as affiliation focuses on the relationship of an individual with others, including partners, family, and friends. This allows one's relationships to be maintained and develop closeness, and to have positive impacts on social interactions with others (Freysinger, 1995). An individual practicing leisure as agency intends for benefits to contribute to self-development. Expected returns of leisure as agency include self-expression, enhanced sense of competency and mastery, and increased self-esteem (Freysinger, 1995). To identify the benefits of airplane piloting as serious leisure, I compared the experiences and attitudes held by the women in each category and then looked at how the categories compared to each other. 


\section{Independent Pilots}

There were six women that fit the description of independent pilots. All six of these women preferred to be interviewed through e-mail. They all exhibited signs of intrinsic motivation and were self-motivated in their involvement of airplane piloting as leisure. Most of the independent pilots were single when they became pilots, and some later married men who were also pilots. All independent pilots had earned college degrees, half at the bachelor level and half at the doctorate level. They were accomplished and successful in high level positions in their careers. All had entered male-dominated career fields and were not intimidated to enter into male-dominated leisure.

It's great to be a woman pilot. The business I started and owned for 20 plus years was in a very male-dominated field, so being a pilot just seemed natural. I think I scared away a couple of dates who were intimidated by a woman who was more accomplished than they, but who wants those types anyway? (Kelly)

As female pilots, they were a significant minority and I asked if this presented any problems for them. I asked if they felt that women being pilots went against traditional gender roles, and the responses of independent pilots consisted of:

Horsefeathers. (Nancy)

Most women aren't adventurous either. It takes someone who has a very different outlook, who likes math and science, and the 3 dimensional freedom of movement. (Kelly)

Women are now being accepted in roles traditionally held by men, therefore, why can't women be pilots? (Alice)

I think the initial barriers of women flying were breached in the 1930s with Amelia Earhart and other highly visible women racing, breaking records, etc. Now, women are astronauts, women are military pilots, so I think there are less institutionally-imposed gender roles. There are other reasons (time, money) why there are fewer women flying today. (Claire) 
I am a professional person, who has been breaking gender barriers for so long I do not even realize that they exist anymore, or perhaps they really do not anymore. Thirty years ago I may have given it thought, but in this day and age there are very few vocations or pastimes that have not been penetrated by women (Sheila)

Basically, as far as gender, I think a pilot is a pilot, and well- respected by both genders if he/she is a good one. In my experience this was not always true. When I was about to take the exam for flight instructor, I was told that the examiner would be hard on me because I was a woman. This was in 1973. My instrument instructor often doled out praise sparingly, saying only "That was pretty good ... for a woman." I think really that that has all changed now. My feeling is that there are still some grudges held against women pilots by airline people, but not in general aviation -- our leisure flying. (Vera)

Independent pilots did not feel restricted by the concept of gender roles and the expectations of appropriate activities for women and all but one indicated that airplane piloting is a "gender-free" leisure space.

Well, I am just as good a pilot as any man, but there are only 2 female pilots at my airport and probably $150 \mathrm{men}$. So is it gender related? Why is the $6 \%$ not changing? It's been the same since I started flying 20 years ago. I sincerely believe that female pilots are better pilots than men. We are more cautious, take our training more seriously, and are very confident of our skills... The plane doesn't care whether a female or male is flying it so I really don't think too much about being in a significant minority. Since I have my network of lady pilots I really don't feel the discrimination when in the air or on the race. But I do feel the discrimination when at my airport. (Alice)

The findings that independent pilots report that airplane piloting is, for the most part, gender free, demonstrates gender negotiation techniques similar to findings among women who engage in skydiving and snowboarding (Laurendeau and Sharara, 2008). They found three strategies of negotiating gender by women in male-dominated leisure activities: avoidance, downplaying gender, and underscoring benefits. The primary gender negotiation technique found among independent pilots is downplaying gender, and is reflected by remarks such as "the airplane does not know who is piloting the 
airplane," "I was raised like a tomboy," "I engage in a lot of pass times that are considered primarily male dominated activities," "gender barriers of old have now long been smashed," and "women are free to pursue almost anything they desire." This demonstrated that gender does matter, yet independent pilots had demonstrated in areas other than their leisure that they were capable of overcoming gender hurdles and excelling as women in careers that were traditionally and predominately held by men.

The ability to obtain durable personal and social benefits from engaging in leisure is a quality that distinguishes serious leisure (Stebbins, 1992). It was found that all the women in this study, regardless of their initial motivation, demonstrated self-actualization in their development of knowledge and mastering of skills. The benefit of selfenrichment refers to the ability to increase the quality of life and values attached to one's own experiences. Participation in serious leisure allows one to find a venue to creatively and actively express one's self. Success in achieving a goal, such as developing a new skill or gaining a certain level of expertise in serious leisure allows one to obtain a feeling of accomplishment and heightened self-esteem. Several of the women recognized that piloting made them feel more self-confident, competent, and empowered.

I have made huge leaps with self confidence. Setting and achieving the goal of becoming a pilot is probably one of the larger challenges I have conquered in my lifetime, the benefit to my psyche is immeasurable.

(Sheila, age 53)

Flying certainly provides an incredible satisfaction for the person - it is such a tremendous accomplishment and I marvel each time I fly... I am proud of my accomplishment as a pilot; it has reinforced in my mind that I can do just about anything I put my mind to. (Alice, age 70)

Independent pilots developed a stronger sense of self and self image from serious leisure involvement. They felt that their status as pilots sometimes garnered reactions of 
respect and also of envy. Whenever interest in aviation was expressed by others, they would be encouraging and provide information about it. They were seldom intimidated to share their identities as pilots. One woman pointed out that she was reluctant to tell certain people that she was a pilot if she expected that they would think that she was boasting. This brought up the point that all the women in this study identified as middle or upper-middle class and they admitted that there is very little racial diversity among the pilots in their social circle. This indicated that airplane piloting as leisure appears to demonstrate class and race privilege, but data did not definitively confirm this.

It's kind of fun to get envious looks from GUYS. (Kelly)

People who do not fly treat me as though I could walk on water. Whereas I might otherwise be ignored, now they always ask me if $I$ have been flying lately, or something similar; a whole lot of respect. (Vera, age 85)

Very often I do not mention my flying to people outside the local aviation "community" because of the fact that it is a unique activity. Some people other than close friends seem to be put off if I mention that I am a pilot, I do not know if it is some kind of envy or if they feel I am boastful.

(Sheila, age 53)

People are surprised that I am a pilot. Probably because I am a woman, and a senior citizen! I respond by telling them about my experiences, I've landed in all 48 contiguous United States and Canada, and I race airplanes. That is the WOW factor, for sure! (Alice, age 70)

Self-gratification and re-creation are benefits of serious leisure found among the experiences of independent pilots. According to Kelly, 59, "Flying is most of all fun and is a stress-reliever." Claire found that flying enabled her to "reset" herself and jokingly added "I'd be on drugs, antidepressants, if I did not fly."

When my life gets too cluttered up with problems and challenges, the best thing that I can do is to take my airplane out for a ride. I remember that when I was first learning, I was working a different shift around the clock every week, and consequently very tired all the time. Sometimes I thought I was too tired to drive to the airport. Once in the air, I could look down at 
how small everything looked, and put my troubles into perspective as being tiny also. I would come back totally refreshed. Still happens. (Vera, age 85)

Vera turned her pastime of piloting into a career as a certified flight instructor, which provided a financial reward. She also earned respect and acknowledgement by receiving the Wright Brothers Master Pilot Award from the Federal Aviation Administration for 50 years of continuous and safe flying in 2007. Independent pilots also found that flying for pleasure led to deeper levels of involvement in the social world of aviation. I found that independent pilots provided leadership in local chapters of the 99s, provided volunteer services as pilots, and participated in air races. This multiple roles in aviation stemming from piloting as leisure demonstrated the concept of mixed serious leisure. Mixed serious leisure is defined in serious leisure theory as "involvement in two or more types or subtypes of serious leisure that, together, constitute for the participant an integrated pursuit of a more encompassing free-time activity than either of the two pursued alone" (Stebbins, 2007, p. 34).

Other benefits of serious leisure are the social interaction and sense of belonging. In many leisure activities, this development of close personal relationships and of feelings of community membership is not only a benefit, but often for purpose of engagement (Brown, McGuire and Voelkl, 2008). Several independent pilots stressed that the social aspect of piloting was very important to them. The data revealed that the social interaction of piloting extends beyond the cockpit. The actual activity of piloting an airplane is limited to sharing the experience with one co-pilot and the maximum number of individuals a small aircraft can carry. The aircrafts typically flown by private pilots had the capacity for a pilot and three passengers. So much of the social 
interactions of pilots took place outside of the actual performance of piloting an airplane. The social relationships with other pilots occurred at airports, aviation events such as flyins, and through associations and organizations that form around aviation. Events and organizations provided women pilots the opportunities to find and form relationships others with shared interests.

Leisure is a group phenomenon that is strengthened through the interpersonal relationships of participants. It is through the concept of social worlds that leisure can be understood for its cohesive function as well as understanding how social relationships support leisure engagement (Kyle and Chick, 2002). Engaging in airplane piloting as a leisure activity allows membership in the social world of aviators. A social world is a social object that is dependent upon effective communication connecting social strata and geographic boundaries (Unruh, 1979). Social worlds do not need any central authority, formal regulations, or list of members. Differentiation of specialized interests, member characteristics, or physical location creates subworlds within the larger social world (Scott and Godbey, 1992; Unruh, 1979). The use of the term social world is interchangeable with the term community.

A key element of the women's experience of piloting as leisure revolves around the social element of leisure. All of the women categorized as independent pilots are members of the 99s, a female pilot-only organization. Most of the independent pilots are members of at least four pilot organizations.

Socially I have met an impressive group of pilots who share the same love and our times together are just plain fun! The 99s organization has given me a network of ladies who share the passion. And through this group I have branched out to the Air Race Classic, a transcontinental air race for women, which is supported by the 99s. (Alice) 
Friendships with other women who were committed to piloting contributed to long-term involvement in the leisure activity. The importance of friendship among others involved in a serious leisure emerged as a core category in previous studies of serious leisure (Brown, McGuire, and Voelkl, 2008; Gibson, Willming, and Holdnak, 2002; Hunt, 2008; Stalp, Radina, and Lynch, 2008; Stebbins, 1992). The social element enables women pilots to become a part of an exclusive community that connects other women pilots from all over the world. Through annual international conferences and their internet network, the members provided encouragement, inspiration, and emotional support for one another, as well as educational benefits, opportunities for volunteering, and fun through social activities.

Local and regional meetings and events provide frequent face-to-face interaction with women who often shared more than their involvement in piloting. According to many of the independent pilots, piloting attracts certain types of people. As Sheila said:

It is wonderful to have access to so many other women who are of like mind. We are all much more self confident, adventuresome and willing to explore different opportunities than the average woman. We have all conquered the complexities of learning to fly which has helped us to feel comfortable about trying other new things and exploring new places both together as a group and as individuals.

In addition to finding like-minded women, being a part of the social world of piloting allowed the sharing of their passion of flying. Independent pilots described their passion for flying with positively and with emotion:

Cherish the times when I am in the air ... I am in awe each time I fly... I tingled when I was first learning ... I love the times I am in control in the air (Alice)

To me flying is something very special ... Whenever I fly a feeling of joy unmatched by anything overcomes me (Shelia) 
Flying just becomes such a vital part of one's life that it is impossible to think of life without it ...It is somehow knowing that we were not born to do this, but somehow have this wonderful magic carpet which can take us in any direction which looks interesting. (Vera)

Aside from durable personal and social benefits that were expected from serious leisure, independent pilots reported experiencing several other benefits from flying. Half of the independent pilots stated that they realized more self confidence from flying airplanes.

Yes, I certainly enjoy the fact that I am able to do something that relatively few people are able to do. It gives me lots of confidence and status. (Vera)

The other independent pilots credit the self confidence they had already acquired in life as a component in their goal of piloting.

...the self confidence to approach the challenge without intimidation.

(Sheila)

I found that independent pilots saw piloting as a unique form of leisure that provided them with distinctiveness.

... willingness to go "out of the box," out of my comfort zone and be challenged. (Alice)

I have found I have a boldness and willingness to take risks where others may not, and I do not fear consequences. (Claire)

This distinctiveness was based upon their own personalities that they held when becoming pilots. It wasn't that they felt piloting made them different but that they already considered themselves different from most women.

I've always been different from my non-flying friends. They all seem to ask: Aren't you AFRAID? Absolutely not! We all have that sense of adventure missing from most women. (Kelly)

No sense of limitation. (Nancy) 
I found that they saw all women who become pilots to hold characteristics that set them apart from the majority of women. They described women who are involved in airplane piloting with the following qualities and situations:

Determination, stick-to-it-iveness, pluck, refusal to be defeated, goalorientedness, self-confidence, a hint of rebelliousness, persistence, love of freedom, clear-headedness, pragmatism, optimism, basic intelligence. (Nancy)

Most have the means and the education to both afford it and to master all of the different disciplines necessary to become licensed. (Sheila)

Women who fly are less intimidated with mechanical things, and generally have a strong sense-of-self (not looking for approval/permission), are confident, independent women with high expectations. (Claire)

Several of the independent pilots who were single when they became pilots later married men who were also pilots. Meeting a significant other through piloting is a benefit of participating in serious leisure.

I met my husband in Las Vegas airport, where I was working, in 1950. He was learning to fly and he owned an airplane. We were married two months later. I was actually engaged to someone else who had been shot down during the war and hated airplanes after that, but when I was learning to fly I just could not imagine spending my life with someone who did not like flying. It was just a whole new world of magic. (Vera)

I found several other personal and social benefits identified by independent pilots as they described the meaning, purpose, and experiences of flying:

...pleasure, excitement, travel, keeping my mind fit. (Kelly)

... an additional dimension to life, a unique perspective on the world and the universe, new glimpses of beauty, a special discipline of the mind, broader horizons, including new and interesting people in my life, and an additional way to serve society. (Nancy)

... camaraderie of fellow female pilots. (Alice)

... exhilaration, a feeling of freedom not found in any other activity. (Sheila) 
... a thrill like no other (Claire)

... my outlet, something I do just for myself. (Alice)

... dominion, humility, focus, clarity of thought, discipline, gratitude, perspective, control, freedom, confidence. (Nancy)

... mostly content and fulfilled, sometimes scared out of my wits. (Sheila)

As expected, I found that independent pilots experience intrinsic rewards from their intrinsically motivated participation in piloting as serious leisure. In the next section, I examine the findings of interdependent pilots.

\section{Interdependent Pilots}

There were six women that fit the description of interdependent pilots. I interviewed three of the women by telephone and three through e-mail. The main difference found among interdependent pilots and independent pilots was that they all engaged in piloting with a husband or boyfriend as a shared leisure activity at or near the beginning of their involvement in airplane piloting. I found that some women held an interest in piloting but did not take pursue this interest until being motivated to engage in piloting as a shared activity with their significant other. Some of the other women said that they held no interest in becoming a pilot until suggested by their partner. The main point of distinction among interdependent pilots is that men play an important and facilitating role in their entry into aviation.

All of the interdependent pilots were married or partnered when they became pilots. Half of the women engaged in shared leisure piloting had children, although only one of the women learned to fly while her children were quite young. All of the women identified as middle, or upper-middle class, except one who identified as middle working class. All independent pilots had earned college degrees. Two of the women had 
associate degrees, three held master's degrees and one held a law degree. Two of the interdependent pilots had retired from careers as school teachers. One woman was a retired office manager and another was a retired lawyer. Two of the interdependent pilots interviewed were still actively employed, one as a registered nurse and the other as a corporate executive. The majority of interdependent pilots had made worked in careers that were predominately female. Even though women pilots are participating in a maledominated leisure, I found mixed attitudes regarding women's rights, gender roles and feminism.

I've always wanted to do interesting things, ever since I was a little kid. And the typical jobs that a woman supposed to do did not sound interesting. ...I never understood why women shouldn't be able to do what men enjoy doing...I was in the vanguard. When I graduated from law school, it was the belief that women could not get jobs in industry. I've always been pushing into the man's world. (Elaine)

I did believe in the feminist movement to a large part, however I do believe they blew it on one point and that is we are women and we should use that power to get what we want. And believe me I have; it just a matter of knowing how and when to use it properly. Sometimes it's very advantageous to be the little stupid blond. I guess it comes down to intelligence and compromise again. (Dana)

Actually I thought the women libbers were a bunch of dumb heads. I thought who wants to give up the right to have the door opened for them, who wants to have basic niceties taken away. I know a lot of it was the work, that was the big thing, they wanted equal pay for equal work, things like that, and I though yeah, I did agree with that part of it, but the rest of it they were touting and the protesting, I thought there were much better ways to do things than to protest. And I never got into that. I never got into the 60s movement and all that. (June)

I asked interdependent pilots if they felt that women becoming airplane pilots challenged gender roles. I found that many women downplayed gender, which was the same gender negotiation technique used by independent pilots. 
When I first started learning to fly, and now you're talking over forty years ago, I had the perception that you had to be like a drill sergeant in the army; that feminine women couldn't do things like that. And it took me thirty seconds to figure out that the airplane didn't know if it was a man or a woman flying it. (Tina)

I would say gender doesn't apply but skill and knowledge does matter. (Betty)

Since most of my life I have done things that most women don't, I did not pay attention to this and I feel the men didn't have any problem with this either. Most pilots are only interested in sharing stories or learning from other pilots, they don't care what gender you are unless you make an issue of this yourself. In other words if you going to throw this in their face then they don't want to bother with you. But if you're going to get down and get to business, they have no problem with that. You have to understand men. (Dana)

I used to [think piloting goes against traditional gender roles], but now the way the world is going, anybody can be anything. So I think we're seeing a lot more branching out, we're seeing a lot more women in the military, seeing a lot more women doing unusual jobs that are non-traditional jobs, plumbers, electricians, mechanics, airplane or car mechanic. I see women are starting to feel that if they want to do something they can. (June)

Any woman who's a pilot gets to "play with the men more" because, just by sheer numbers and I think there has always been, on my part at least, a sort of a striving to say I can do it and I can do it just as well as you can. Some women probably back away and say they're intimidated by it but I tend to take the opposite opinion and say that I can do it. (Tina)

When I asked if they felt that airplane piloting was a "gender-free" leisure space or if they thought that there was gender equality in airplane piloting, only Dana denied that it was by responding, "Not entirely but close." Other women made statements implying that gender did not matter in general aviation.

The airplane doesn't know the difference in sex. (Betty)

Yeah ... anybody can fly, if they have the aptitude for it, if they can pass the test, and but whether they can all become professional or commercial, that's another thing. But I think everybody has a chance to fly if they want it and if they can pass the test... I think anybody should do it, whether it's a man or a woman. (June) 
A key difference between interdependent and independent piloting is the importance place upon piloting as shared leisure. I asked interdependent pilots to tell me about benefits from sharing piloting with their husband or partner.

We both love flying and being in the air sightseeing is fun to share. (Betty)

I really believe our involvement in flying was a great asset to our marriage (we did not have children of our own, but enjoyed taking many young people flying). We had always enjoyed working together as well as having fun camping, hiking, snow skiing, woodworking, gardening and even shopping. (Wanda)

My boyfriend is a pilot. We fly a lot together and go to a lot of flying activities. So in a way it keeps us together. When he can't fly I do the flying and when I can't he will pick up the slack (medical issues). (Dana)

I don't think we would have stayed married as long as we did if we weren't flying. [How long were you married?] 25 years. We had other activities, but flying was our hobby. We didn't take vacation except to do flying. We learned about flying together, we quizzed each other on the aviation alphabet when we were driving, to help each other remember it. I would always do nasty things to him by throwing the circuit breaker of the landing gear during a practice approach to see if he noticed. He never could sneak enough to do that to me, he tried. We did things to keep each other sharp that were safe. They were the type of things a flight instructor would do. (Elaine)

Most of the interdependent pilots said that piloting together with their husbands or partners contributed to the relationship. When I asked June to indicate what aspect of flying for shared leisure was most important to her, she indicated that three purposes are very important in piloting as shared leisure: To serve as a helper during flights, to share a hobby they both equally enjoyed and to take over if one were to become ill. When I asked Tina if sharing piloting has enriched their relationship, she responded "Kind hard to say, umm, we both had different instructors and we were taught to do things in different ways and sometimes that has created conflict and sometimes it hasn't. Umm, it's kind of a balance. It hasn't always been $100 \%$ agreement, let's put it that way." Like 
other women interviewed by telephone, her husband was sitting nearby, which could have attributed to her response.

Most of the interdependent pilots stated that they probably would have become pilots on their own if not with their husbands or partners. But Elaine said that she would not have:

I didn't have any interest in it. It just never occurred to me that it would be a hobby that I would enjoy. I expected him to say "Nah, not interested." Or something like that. I didn't expect that I would get such enthusiasm. I was looking at it strictly as transportation. And I thought it would be a cool way to get from point $A$ to point $B$.

Most interdependent pilots said that they had a passion for flying, although a couple of them described their passion had faded with time. I found that the degree of emotion expressed in descriptions of their passion for flying was less for interdependent pilots compared to independent pilots.

Passion of flight: It means when I wake up in the morning I am smiling from ear to ear and so happy to know I get to go flying today.(Betty)

When I fly I feel good all day. It's such a thrill. (Dana)

I think having a family was the greatest passion I ever had, raising my kids, until flying came along. And that kind of superseded it only because the kids are out of the house. (June)

It changed a little bit, I still have the passion for aviation. I don't feel as compelled to fly. It's a little bit like I've been there and done that. It's something that I've mastered and I can move on and do other things. (Elaine)

When my husband had a medical problem and I had to come up to speed, not only in basic flying but in instrument flying which I hadn't done in about 13 years. All the old enthusiasm came flying right back and now I'm as passionate as ever. (Tina) 
I found several durable personal benefits expressed among interdependent pilots that were similarly found among independent pilots, yet independent pilots expressed more benefits than interdependent pilots.

Sense of enjoyment:

I always feel happy after having flown. (Betty)

Improved self-image:

It opens up another opportunity for me to gain more respect and have friends in all walks of life. (Betty)

I am definitely a lot poorer, but have a whole lot more self respect. (Dana)

\section{Social interaction:}

A way to enjoy life, meet new people and places (Wanda)

It opened up horizons that are unbelievable. Just meeting people throughout the United States, participating nationally, knowing nationally what is going on in aviation right now. During the winter I live on an aviation community and so all of our social activities are revolving around general aviation. (Tina)

\section{Sense of accomplishment:}

My whole world changed when I learned to fly - the self satisfaction that I could accomplish this, my family's feeling of what I accomplished, my new found friends in the 99s and other flying activities - and I am proud I did it and have never regretted any part of this exhilarating experience (Wanda)

Being able to accomplish something that few others can (Dana)

\section{Self-confidence:}

Yes, not only the confidence in making decisions, but reasoning out problems differently, making decisions on the split notice, before I might had sat back and taken quite a bit longer in making a decision about something only because sometimes time is of the essence (June) 
Sense of competency:

There's such a sense when you are fully flying within your limits and you are competent and you are doing something that is difficult. You stay so focused on it that you have the buildup of tensions and when you successfully accomplish it, there's such a release of that tension from having done something that is fairly difficult. (Elaine)

\section{Re-creation:}

I find sometimes that it clears out your head and make things make more sense. If I have a problem or something and I' $m$ not quite sure how to figure out, a lot of time I'll go flying for that reason. Just a release, flying, I'll go up for a little bit and figure it out, away from everybody, and there's nobody around (June)

\section{Provides thrills:}

Yes, it's a thrill and yes it's a kind of relaxation, but I don't always look at it as a thrill.(June)

It's such a thrill. I would also like to add it's a safe thrill. (Dana)

Sense of competency:

There's such a sense when you are fully flying within your limits and you are competent and you are doing something that is difficult. You stay so focused on it that you have the buildup of tensions and when you successfully accomplish it, there's such a release of that tension from having done something that is fairly difficult. (Elaine)

Sense of freedom:

Freedom, ultimate freedom. (Betty)

\section{Empowerment:}

The empowerment and self-esteem is over welling (Dana)

I found intrinsic benefits being realized by these women who were extrinsically motivated at the level integrated regulation. Since self-determination takes place at this degree of extrinsic motivation, according to Deci and Ryan (2000), this would be expected. 
All of the interdependent pilots belonged to at least two piloting organizations,

one of which was the 99s. I found that most of the women who reported holding national

leadership positions in the $99 \mathrm{~s}$ were among the interdependent pilots. All of the women

in this category emphasized that being a member of a women-only piloting was an

important part of their piloting experience.

The social relationships with other pilots for me are very important. As I said many of my best friends are pilots (male and female). It is unique enough only a pilot can understand a lot of what you may want to talk about. As a matter of fact, when I first learned to fly I was so excited about flying but, my non pilot friends didn't want to talk about it anymore they were bored with my excitement or something. They couldn't relate. I needed some pilot friends to talk to. That brought up another problem, most pilots are men. I also needed some woman pilots to talk to. Partly because I was a married lady, and partly because the men dominated the conversation with all their knowledge when I was a student pilot. I wanted to share what I was experiencing. I organized a local 99s chapter with two of my lady pilot friends and have always enjoyed our local 99 chapter. I have made some really good friends. (Betty)

When my husband passed away just two years ago this week, I heard from many $99 \mathrm{~s}$ from around the world telling me what an asset he had been to the $99 \mathrm{~s}$ and he would be greatly missed. They are still a very great support for me and I love them all. (Wanda)

It's the fact that there is a group of people that actually have the same interests. You can share with these people things that other have no clue about. I'm not a big social group person, but the girls in my 99 chapter have become my best friends and we do many other activities together.

(Dana)

I think the $99 \mathrm{~s}$ is very unique. They are a social group, they're a sisterhood, and there is nothing like it in the world. Maybe the Russian women's organization might come close but I don't think there is any other organization. (June)

[The most significant benefit of being a member of the $99 \mathrm{~s}$ ] is the camaraderie and the exchange of information. Because I truly believe in many cases, women pilots see things differently than men pilots. We explain things to each other, we support each other, and we examine the different kinds of opinion and things that have come about in aviation.

(Tina) 
Like independent pilots, all of the interdependent pilots enjoyed flying with other women pilots. They found opportunities to serve the community of female pilots, the broader community of aviation, and the community outside of aviation. Many of the women in both interdependent and independent categories of pilots engaged in various forms of volunteering, yet I found that interdependent pilots were more invested in promoting and supporting women piloting. Although interdependent pilots realized many of the same benefits as independent pilots, an important difference was that they engaged in piloting as a shared leisure activity with their significant others. As shared leisure, airplane piloting with a partner provided positive benefits to the significant relationship. This aspect of piloting was also found in the final category of women pilots, the dependent pilots.

\section{Dependent Pilots}

A major distinction found among this third category of pilots is the absence of self-determination, which is defined as "the feeling of being the origin of the activity" (Shamir, 1992, pg. 303). Dependent pilots engage in companionate leisure (Crawford, Houts, Huston and George, 2002) and practice leisure as affiliation (Freysiner, 1995). Each of the four women that I identified as dependent pilots demonstrated that their involvement in airplane piloting would not have taken place if not for the influential role of their significant other. Two of the dependent pilots had flown with their husbands for several years prior to deciding to become pilots also. They each first looked into taking pinch-hitting courses to learn how to take over control of the airplane in the event of the pilot-in-command becoming incapacitated. But both of them decided to earn their private pilot certificates for the purpose of flying with their husbands. One woman decided to 
take lessons as her boyfriend learned to fly. She wanted to fly with him, but also wanted to feel secure that she would be able to pilot the airplane in the case of emergency. She said that she was motivated by self-preservation. A fourth woman had always wanted to become a pilot but had never acted upon it until being encouraged to pursue it by a pilot who later became her husband.

All of the dependent pilots stated that they would not have become pilots had it not been a leisure pursuit of their significant others. I found clear indication that the primary purpose of their initial involvement in piloting was directed toward spending time together with their partners which contributed positively to their significant relationships.

Of the four women that I identified as dependent pilots, three of them began piloting after their responsibilities of raising their children had eased. The other dependent pilot, Lois, began flying at age 25 and never had children. While taking flight lessons, Lois heard about opportunities to become an air traffic controller. She attributes finding her career through her leisure pursuit. I asked Lois about her experience of entering into a male-dominated career field and also a male-dominated leisure space:

It feels great - not only being a pilot but I was an air traffic controller and I don't know how they got to be MENS jobs - it's been proven that women are actually better at these things - why do you think the voice on the GPS is a woman. My parents never put any limitations on me - there was no talk about not being able to do things because it was a man's job.

When I asked Lois, in an e-mail interview, how she would react to someone telling her that only men should become pilots she responded "I would kick them where it hurts - well maybe not that drastic but they would know that I did not agree with that." 
Paula had always dreamed of being a pilot, but had never acted on it until making a friend at her work, which unknown to her, was a pilot. After sharing her desire to learn to fly, he encouraged her to pursue it. This led to learning to fly and getting married to him. Her purpose of following through on her dream was to engage in piloting with her new husband. When I asked Paula about women becoming involved in male-dominated leisure she said "Did anybody ever say, oh, you're just a girl? Maybe. Maybe it's a California thing, I don't know."

Rachel and Gloria were both homemakers whose husbands began flying more once their children were into adolescence. I found similarities in their stories of becoming pilots during their telephone interviews. Both of them had flown often with their husbands and decided that becoming a pilot would increase the amount of time that they spent with their husbands. When I asked Rachel if anyone had ever told her that only men are pilots, she said "No, I never have really, because I think that people that we associate with generally, uh, they're really, accepting of "do whatever you want to", you know, if you want to try racing or motorcycling or whatever."

All of the dependent pilots stated that they would not have become pilots without being influence by the men in their lives. When I asked about having a passion for flying, Lois replied "I was probably passionate when I started, but 30 years later-it's like driving my car." All of the other women said that they did not have a passion for flying, but that their husbands did.

They all reported that flying for vacations was an important part of companionate piloting. They emphasized the enjoyment of sharing trips with their husbands and their roles as a helper or navigator. Lois's husband stopped flying due to a medical issue and 
she became the pilot in command while her husband flew as her helper. I asked the dependent pilots if piloting was a significant aspect of their life. Lois found that piloting was a more significant part of her life after her retirement. Gloria felt that piloting was a significant accomplishment in her life, although it was never as significant aspect of her life as it was for others:

I do kind of think for all that's made of it, it does seem like much of the big deal to other people, on the other hand, I didn't really pursue it as much as allot of women do, like the ones who immediately go on to get there instrument ratings, get multi, and commercial and then even maybe become a career pilots. But even the ones who don't do it as a career, I didn't get that far into it. I still feel that it was an accomplishment for me.

Paula also saw becoming a pilot as a significant accomplishment and found her engagement in the $99 \mathrm{~s}$ to be very important to her. Paula and her husband decided that they would join separate piloting organizations, as she described:

We made a conscious decision. I joined the 99 s to meet people who have the same interest and hopefully to become friends, which of course happened. My husband joined at that same time, he a group at a naval base close near here, they had some planes that he wanted to learn to fly, for the same basic reason that he would be with people who guys who flew and sure enough. We've made some very good, good friends through both organizations.

Rachel did not feel that piloting was a significant aspect of her life, nor did she pursue membership in the $99 \mathrm{~s}$, or any other piloting organization. She did participate in piloting events, such as attending the annual piloting event held by EAA at Oshkosh.

Benefits found were mostly focused on the relationships with the partners of the dependent pilots. Travel for vacations was the key purpose of airplane piloting. Yet most of the dependent pilots did receive benefits through their participation in the $99 \mathrm{~s}$. They were able to find friends, serve in positions of leadership, volunteer opportunities, and camaraderie with other women pilots. They felt that others were surprised and 
impressed that they were pilots, or as Gloria put it, "something more than being a housewife."

I did find that dependent pilots realized intrinsic benefits from airplane piloting along with the external reward of maintaining closeness in their significant relationships.

It was something that was a major accomplishment for me. Just knowing that I did that gives you a lot of confidence passed and the check flight was something that I had dreaded. It made me probably as nervous as I've ever been in my life and when I got that done, I was extremely happy. (Paula)

I still feel that it was an accomplishment for me. (Gloria)

If I could get my license, that was quite an accomplishment. It felt like, you know, I had done something that not everybody else does. (Rachel)

Things that happen in the future were less challenging. I felt more selfconfidence. (Paula)

I'm proud of the fact that I did it. (Gloria)

If I go back to my hometown, which I do and I know people there and I talk about flying you know, they look at me as if I said I've been to Mars. But at the same time goes Wow! That's a good feeling, it helps your selfimage. I'm sure. It changed my self-image a little bit, but I wasn't really surprised that I could do it. I'm more surprised that I did go ahead and do. (Paula)

I did not find as many benefits of piloting expressed by dependent pilots as by independent and interdependent pilots. Their primary focus was flying as affiliative leisure. Although they did talk about making friends with other women pilots through the 99s, they emphasized the support network more than close friendships as a benefit of being a member of the 99s. A significant finding was that dependent pilots did experience a degree of intrinsic rewards such as a sense of accomplishment, a heighten self-image, pride and a sense of belonging to the community of women pilots. 
Table 2 provides a listing of the benefits reported by women who engaged in airplane piloting as serious leisure. The table allows a comparison of the benefits realized by the three different categories of women pilots, by indicating the number of women in each category reporting the various benefits presented.

The personal benefits that were most often expressed by all three categories of pilots included an increase in self-confidence, increase in self-image, sense of accomplishment, and the sense of excitement, thrill and adventure. With the exception of the sense of excitement, thrill and adventure, the most often reported benefits of piloting were intrinsic rewards that are found through engagement in self-determined activities. These all represented leisure as agency, in that the rewards are directed toward selffulfillment.

The most often reported social benefits were belonging to women's piloting organizations. It is through active membership in women's piloting organizations that women find other women with similar interests in flying and form friendships. Forming friendships through flying was another social benefit most often reported.

Many women reported the importance of being able to travel by airplane for vacations, day-trips, or sight-seeing. This was what I referred to as a functional benefit of airplane piloting as serious leisure. The advantage of being qualified to pilot an airplane and the availability of the aircraft increases the convenience and frequency of air travel. As was brought out by some of the participants, being able to fly their own plane to as a form of transportation allows one to compress their free-time in order to engage in other activities that they enjoy. 
Table 2

Comparison of Categories of Women Pilots

\begin{tabular}{|c|c|c|c|}
\hline $\begin{array}{l}\text { Benefits of piloting airplanes as } \\
\text { serious leisure described by women }\end{array}$ & $\begin{array}{c}\text { Independent } \\
\text { Pilots } \\
\mathrm{N}=6\end{array}$ & $\begin{array}{c}\text { Interdependent } \\
\text { Pilots } \\
\mathrm{N}=6 \\
\end{array}$ & $\begin{array}{c}\text { Dependent } \\
\text { Pilots } \\
\mathrm{N}=4 \\
\end{array}$ \\
\hline Increase in self-confidence & 6 & 6 & 4 \\
\hline Travel to new places and vacations & 6 & 5 & 4 \\
\hline $\begin{array}{l}\text { Membership in women's piloting } \\
\text { organization(s) }\end{array}$ & 6 & 6 & 3 \\
\hline Increase in self-image & 5 & 6 & 4 \\
\hline Formed friendships through flying & 6 & 6 & 3 \\
\hline Sense of accomplishment & 5 & 6 & 3 \\
\hline $\begin{array}{l}\text { Provided excitement, thrill or } \\
\text { adventure }\end{array}$ & 6 & 4 & 4 \\
\hline Piloting changed life & 5 & 6 & 2 \\
\hline Flying contributed to identity & 5 & 4 & 3 \\
\hline Self-gratification & 5 & 6 & 0 \\
\hline Found a passion for flying & 6 & 5 & 0 \\
\hline $\begin{array}{l}\text { Felt unique, did something rarely done } \\
\text { by others }\end{array}$ & 4 & 4 & 3 \\
\hline Provided volunteer services as pilots & 4 & 5 & 1 \\
\hline Provided a challenge & 3 & 5 & 1 \\
\hline $\begin{array}{l}\text { Provided escape, solitude, relaxation, } \\
\text { and peacefulness }\end{array}$ & 4 & 3 & 2 \\
\hline Sense of freedom & 4 & 4 & 1 \\
\hline $\begin{array}{l}\text { Flying contributed positively to } \\
\text { significant relationships }\end{array}$ & 1 & 5 & 3 \\
\hline Feeling of control & 4 & 3 & 1 \\
\hline Spillover benefits to other areas of life & 3 & 4 & 1 \\
\hline Mentor to young pilots & 3 & 4 & 0 \\
\hline $\begin{array}{l}\text { Found network of support and } \\
\text { inspiration }\end{array}$ & 2 & 2 & 3 \\
\hline Empowerment & 3 & 2 & 2 \\
\hline $\begin{array}{l}\text { Sense of belonging to broader } \\
\text { community }\end{array}$ & 3 & 2 & 2 \\
\hline Overcame fears & 2 & 1 & 2 \\
\hline Enjoyment of view from airplane & 3 & 2 & 0 \\
\hline Competed in air races & 2 & 1 & 1 \\
\hline $\begin{array}{l}\text { Leadership opportunities in pilots' } \\
\text { organization (national level) }\end{array}$ & 0 & 3 & 1 \\
\hline $\begin{array}{l}\text { Leadership opportunities in pilots' } \\
\text { organization (local level) }\end{array}$ & 1 & 1 & 1 \\
\hline
\end{tabular}


Summary

This study of women who piloted airplanes as amateurs contributes to the literature of the social phenomenon of leisure. The findings confirmed that amateur airplane pilots exhibited attributes commonly found in the pursuit of careers, thus demonstrating serious leisure (Stebbins, 2007). I closely examined motivations and found that some women were intrinsically motivated (Deci and Ryan, 1985) with a genuine interest in becoming aviators, while others were extrinsically motivated (Deci and Ryan, 1985), in order to share in the activity with significant others. I found that the motivations of the women engaged in companionate piloting, which are I categorized as dependent pilots, demonstrated the introjected regulation level of extrinsic motivation, which has a low level of autonomy. The motivations of women participating in piloting as mutually-determined shared leisure, interdependent pilots, exhibited integrated regulation, which has a high level of autonomy and exhibits self-determination. Further analysis of the findings revealed that women pilots who achieved their private pilot certificates through their own volition and efforts, categorized as independent pilots, were intrinsically motivated. All women who were dependent and interdependent pilots were supported or influenced by men to participate in this male-dominated serious leisure.

Personal and social benefits that were revealed through in-depth interviews were found to be consistent with serious leisure theory's (Stebbins, 2007) durable benefits which represented desirable benefits to a participant's sense of self-fulfillment. The benefits and characteristics of independent, interdependent, and dependent pilots were compared and it was found that outcomes of serious leisure were affected by their motivation to take action. 


\section{CHAPTER V}

\section{DISCUSSION}

The present study sought to identify airplane piloting as serious leisure, describe the motivations of women's pursuit of amateur airplane piloting, and examine the personal and social benefits realized from long-term serious leisure participation. This study applied serious leisure theory (Stebbins, 1992), the concepts of intrinsic and extrinsic motivation as posited by self-determination theory (Deci and Ryan, 1985), and the concepts of other-oriented action and self-oriented action (Freysiner, 1995) to gain insights into women's experiences in this historically male-dominated leisure activity. The main goals of this research were to demonstrate airplane piloting as serious leisure, find how women were drawn into the serious leisure activity of airplane piloting, the personal and social benefits realized from their participation, and how motivation affects the outcomes of serious leisure participation.

The findings of this study show that airplane piloting is a serious leisure activity as practiced by the women involved in this research. I found each of the six qualities identified in serious leisure theory among all of the participants of this study. This examination of women airplane pilots permits insight into several areas of leisure that have significant sociological implications. One such factor addressed in this study is women's involvement in male-dominated leisure space. This study looks at how women feel about being involved in a recreational activity predominately engaged in by men. 
The overall sentiment felt by women pilots is that airplane piloting is a gender-neutral activity. Unlike other studies that focus on the negotiation of gender in male-dominated recreational activities, such as snowboarding (Anderson, 1999; Laurendeau and Sharara, 2008) and motorcycling (Gagne and Austin, forthcoming; Roster, 2007) which found women consciously making adjustment to gender performance in response to their minority status, most women pilots interviewed reported that they had no need to act any differently than they would otherwise. Yet, the findings showed how the women's downplaying of gender in general aviation is a form of gender negotiation.

This study offers an analysis of the various motivations women held for entering into airplane piloting. I found that the majority of women in this study pursued piloting with the assistance or encouragement of men. Yet, several women reported taking up airplane piloting as their own hobby. I applied the theory of self-determination to interpret their motivations as intrinsic or extrinsic. According to this theory, I should have expected that women who demonstrated being highly motivated for the purpose of achieving an external reward would not exhibit any intrinsic rewards from their involvement. This was not the case in this study, in that women who engaged in companionate piloting did experience intrinsic outcomes from their involvement. All of the women in the study become involved in the social world of piloting and found additional benefits from being socially activity in organization. This greater level of involvement served to solidify their identity as pilots and brought about intrinsic rewards. Self-determination theory indicates that extrinsically motivated action which are not selfdetermined do not produce intrinsic rewards, but this static description did not fit with the 
findings of this study in which women moved beyond their initial motivation as their involvement increased.

This study also allows insight into women's resistance of tradition gender roles as seen in the descriptions of how women live and perform gender outside of their leisure time. This is seen by comparing the findings of women who struck out on their own to become pilots compared to women who were led into, or followed along with their husbands or boyfriends. I found a sharp contrast is found when examining the educational levels and career fields that women had already entered, often at a time in which they would have been considered trailblazers, and the women who followed more traditional gender roles. I found that the interdependent and dependent women pilots did not challenge traditional female roles in other areas of their lives, but they did in their leisure roles by becoming airplane pilots. Since this study focused on women who have been pilots for at many years, several of these women became pilots at a time in which many professions were closed to women.

This demonstration of airplane piloting as serious leisure contributes to the understanding of the pursuit of a skill-intensive leisure activity that requires significant time, effort, and money to obtain qualifications required for participation. The findings revealed that long-lasting personal and social benefits realized through airplane piloting as leisure are consistent with the expected durable benefits proposed in serious leisure theory. As outlined by Stebbins (2007), serious leisure provides participants with seven personal benefits: personal enrichment, self-actualization, self-expression, self-image, self-gratification, re-creation, and financial return. With the exception of financial return, these benefits demonstrate intrinsic rewards that are generated from intrinsically 
motivated leisure behavior (Deci and Ryan, 1985). I found that all women in the study reported experience intrinsic rewards from piloting airplanes as serious leisure. I did not expect to find that women who practice leisure as affiliation would have found selfdirected benefits as well, according to the theories applied to this study. Yet, dependent pilots did express several intrinsic, self-directed, benefits as well as the expected external rewards of improved significant relations. Interdependent pilots demonstrated most of the same self-directed rewards from piloting as independent pilots, as well as the same other-directed rewards as reported by the dependent pilots. I found that the independent pilots used more passionate language when talking about their experiences of flying than the other two categories of pilots. Even though several of the independent pilots married pilots after already being involved in piloting, very few stated that flying with their partners were benefits realized through this leisure activity.

Accounts of the functions, meanings, feelings and benefits of piloting airplanes for leisure of the independent pilots reflected that they felt bold, daring and adventurous when piloting. Interdependent pilots were found to be more actively involved in the social world that surrounds aviation than the other categories of pilots. This was demonstrated by the high number of interdependent pilots in leadership roles, volunteering and mentoring new pilots. Dependent pilots' responses reflected that piloting contributed to family leisure and was a quick form of transportation to visit distant people and places. The group of dependent pilots expressed that airplane piloting was challenging and derived much confidence from it. 
Based upon the motivations reported in this study, along with the identification of benefits women pilots experienced from serious leisure involvement, this supports the premise that motivation plays a significant role in the outcomes of serious leisure. 


\section{CHAPTER VI}

\section{CONCLUSION}

The findings from this qualitative study reveal characteristics of women's participation in serious leisure that are unique to activities that entail the requirement of obtaining a legal right to perform the activity. In the United States, it is illegal to operate an airplane without a certified pilot in command, except during solo flights by student pilots. This condition requires individuals desiring to engage in airplane piloting as a recreational activity to invest time, effort, and a considerable amount of money into flight training. Rigid regulations are enforceable through FAA spot inspections. Participation in airplane piloting is an intense and serious endeavor that requires commitment to safety, maintenance of skills and application of specialized knowledge.

This study focused on women who had been airplane pilots for at least 15 years. Further research is warranted to find whether similar situations are prevalent among women pilots with less than 15 years experience. These findings shed light on the subject of women engaged in male-dominated leisure activities. Further research is called for on whether women's participation in male-dominated leisure is conditional upon the encouragement and assistance of men. Another area of women's participation in serious leisure that warrants further investigation is the phenomenon of companionate leisure as an ethic of care issue, since some women found piloting would enable them to fly 
in the event that their husbands or boyfriends became incapacitated.

The interview data of this study do not present a full range of women participating in airplane piloting as serious leisure. Interviewees were recruited at two events, the 2009 annual conference of the Ninety-Nines, Inc. International Organization of Women Pilots held in Chicago, Illinois and the 2009 EAA AirVenture event held in Oshkosh, Wisconsin. The majority of the women meeting the criteria of this study were recruited through the Chicago conference attendees. Several of the respondents of this study were referred by members of the $99 \mathrm{~s}$. For this reason, further research is needed of women pilots who are not members of piloting organizations.

The significant findings of this study demonstrate that women's participation in airplane pilot is serious leisure and as such it is expected that durable personal and social benefits are realized. One of the goals of this study was to discover the various reasons why women become amateur airplane pilots and analyze their motivations according to concepts of intrinsic and extrinsic motivations. The discovery of how women's realized benefits vary based upon category of motivation and forms of participation contribute to the understanding of women's participation in male-dominated serious leisure. Further empirical research would be needed to test if the findings emerged from this study are widespread among women who pilot airplanes as serious leisure.

A study is warranted to determine if this model is specific to only women or to enduring involvement alone. This qualitative study of women's serious leisure involvement is not intended to make broad sweeping generalizations. Rather, the intention is to expose why and how women engage in a high-investment, skill intensive leisure activity that is predominately pursued by men. 


\section{REFERENCES}

Adler, Patricia and Peter Adler. 1987. Membership Roles in Field Research. Newbury Park, CA: Sage.

Alexandris, Konstantinos, Charalambos Tsorbatzoudis, and George Grouios. 2002. "Perceived Constraints on Recreational Sport Participation: Investigating their Relationship with Intrinsic Motivation, Extrinsic Motivation and Amotivation." Journal of Leisure Research 34(3):233-52.

Air Force Personnel Center. 2010. “Demographics.” Retrieved June 10, 2010. http://www.afpc.randolph.af.mil/library/airforcepersonnelstatistics.asp

Arai, Susan, and Alison Pedlar. 2003. "Moving beyond Individualism in Leisure Theory: A Critical Analysis of Concepts of Community and Social Engagement" Leisure Studies 22:185-202.

Arksey, Hilary and Peter T. Knight. 1999. Interviewing for Social Scientists. Thousand Oaks, CA: Sage.

Auster, C. J. 2001. "Transcending Potential Antecedent Leisure Constraints: The Case of Women Motorcycle Operators." Journal of Leisure Research 33:272-98.

Austin, D. Mark, and Patricia Gagne. 2008. "Community in a Mobile Subculture: The World of the Touring Motorcyclist." Studies in Symbolic Interaction 30:41 1-37.

Aversa, Alfred, Jr. 1990. "When Blue Collars and White Collars Meet at Play: The Case of the Yacht Club." Qualitative Sociology 13(1):63-82.

Baldwin, Cheryl K. and Patricia Norris. 1999. "Exploring the Dimensions of Serious Leisure: Love me - Love my Dog." Journal of Leisure Research 31:1-17.

Baldwin, Julia H., Gary D. Ellis, and Bret M. Baldwin. "Marital Satisfaction: An Examination of Its Relationship to Spouse Support and Congruence of Commitment among Runners." Leisure Sciences 21:117-31.

Berg, Ellen C., Melanie Trost, Ingrid E. Schneider, and Maria T. Allison. 2001. "Dyadic Exploration of the Relationship of Leisure Satisfaction, Leisure Time, and Gender to Relationship Satisfaction." Leisure Sciences 23:35-46. 
Bialeschki, M. Deborah, and Sarah Michener. 1994. "Re-entering Leisure: Transition within the Role of Motherhood." Journal of Leisure Research 26(1):57-74.

Bowen, Glenn A. 2006. "Grounded Theory and Sensitizing Concepts." International Journal of Qualitative Methods 5(3):1-9.

Bowen, Glenn A. 2008. "Naturalistic Inquiry and the Saturation Concept: A Research Note." Qualitative Research 8(1):137-52.

Brown, Carroll A. 2007. "The Carolina Shaggers: Dance as Serious Leisure." Journal of Leisure Research 39(4):623-47.

Brown, Carroll A., Francis A. McGuire, and Judith Voelkl. 2008. "The Link between Successful Aging and Serious Leisure." International Journal of Aging and Human 66(1):73-95.

Carroll, Bob, and Konstantinos Alexandris. 1997. "Perception of Constraints and Strength of Motivation: Their Relationship to Recreational Sport Participation in Greece." Journal of Leisure Research 29(3):279-99.

Celsi, Richard L., Randall L. Rose, and Thomas W. Leigh. 1993. "An Exploration of High-Risk Leisure Consumption through Skydiving." Journal of Consumer Research $20: 1-23$.

Charmaz, Kathy. 1983. "The Grounded Theory Method: An Explication and Interpretation." In R. M. Emerson. (Ed.) Contemporary Field Research: A Collection of Readings (Pp. 109-126). Prospect Heights, IL: Waveland Press.

Collinson, Jacquelyn A. and John Hockey. 2007. "Working Out' Identity: Distance Runners and the Management of Disrupted Identity." Leisure Studies 26 (4):381-98.

Corbin, Juliet and Anselm Strauss. 1990. "Grounded Theory Research: Procedures, Canons, and Evaluative Criteria." Qualitative Sociology 13(1):3-21.

Crawford, Duane W., Renate M. Houts, Ted L. Huston, and Laura J. George. 2002. "Compatibility, Leisure, and Satisfaction in Marital Relationships." Journal of Marriage and Family 64(2):433-49.

Csikszentmihalyi, Mihalyi. 1990. Flow: The Psychology of Optimal Experience. New York: Harper Collins.

Deci, Edward, and Richard M. Ryan. 1985. Intrinsic Motivation and Self-determination in Human Behavior. New York: Plenum. 
Deci, Edward, and Richard M. Ryan. 2000. "The "What" and "Why" of Goal Pursuits: Human Needs and the Self-determination of Behavior". Psychological Inquiry 11:22768.

Denzin, Norman K. 1970. The Research Act: A Theoretical Introduction to Sociological Methods. Chicago, IL: Aldine.

Diehm, Rebekah and Christine Armatas. 2004. "Surfing: An Avenue for Socially Acceptable Risk-taking, Satisfying Needs for Sensation Seeking and Experience Seeking." Personality and Individual Differences 36:663-77.

Federal Aviation Administration. 2008 U.S. Civil Airmen Statistics (Updated May 14, 2009). "Table 2 Estimated Active Women Airmen Certificates Held December 31, 19992008." Retrieved June 4, 2009, from

http://www.faa.gov/data_research/aviation_data_statistics/civil_airmen_statistics/2008/.

Fessenden, Nancy Barrett. 2002. Exploring the Experiences of Middle-aged Women in Becoming Private Pilots: A Phenomenological Study. $\mathrm{PhD}$ dissertation, Capella University.

Freysinger, Valeria J. 1995. "The Dialectics of Leisure and Development for Women and Men in Mid-life: An Interpretive Study." Journal of Leisure Research 27(1):61-84.

Gagne, Patricia, and D. Mark Austin. "Playing with the Guys: Women Motorcyclists' Negotiation of Gendered Leisure and Space." International Journal of Motorcycle Studies, forthcoming.

Gahwiler, Pamela and Mark E. Havitz. 1998. "Toward a Relational Understanding of Leisure Social Worlds, Involvement, Psychological Commitment, and Behavioral Loyalty." Leisure Sciences 20:1-23.

Garcia, Angela Cora, Alecea I. Standlee, Jennifer Bechkoff and Yan Cui. 2009. "Ethnographic Approaches to the Internet and Computer-Mediated Communication." Journal of Contemporary Ethnography 38(1):52-84.

Gibson, Heather, Cynthia Willming and Andrew Holdnak. 2002. "We're Gators...Not Just Gator Fans": Serious Leisure and University of Florida Football." Journal of Leisure Research 34(4):397-425.

Glaser, Barney G., and Anselm L. Strauss. 1967. The Discovery of Grounded Theory. Chicago: Aldine.

Goff, Stephen J., Daniel S. Fick, and Robert A. Oppliger. 1997. "The Moderating Effect of Spouse Support on the Relation between Serious Leisure and Spouses' Perceived Leisure-Family Conflict." Journal of Leisure Research 29(1):47-60. 
Gould, James, DeWayne Moore, Francis McGuire and Robert Stebbins. 2008.

"Development of the Serious Leisure Inventory." Journal of Leisure Research 40(1):4768.

Green, Eileen. 1998. "Women Doing Friendship": An Analysis of Women's Leisure as a Site of Identity Construction, Empowerment and Resistance." Leisure Studies 7:171-85.

Hesse-Biber, Sharlene and Patricia Lina Leavy. 2007. Feminist Research Practice. Thousand Oaks, CA: Sage

Hill, Martha S. 1988. "Marital Stability and Spouses' Shared Time." Journal of Family Issues. 9(4):427-51.

Huberman, A. Michael and Matthew B. Miles. 1994. "Data Management and Analysis Methods." In N. Denzin \& Y. Lincoln (Eds.). Handbook of Qualitative Research (pp. 428-44). Thousand Oaks, CA: Sage.

Hunt, Jennifer. 1995. "Divers' Accounts of Normal Risk." Symbolic Interaction 18(4):439-62.

Hunt, Stephen. 2008. "But We're Men Aren't We! Living History as a Site of Masculine Identity Construction." Men and Masculinities 10:460-83.

Hunter, David R. 2006. "Risk Perception among General Aviation Pilots." The International Journal of Aviation Psychology 16(2):135-44.

Iso-Ahola, Seppo E. 1980. Social Psychological Perspectives on Leisure and Recreation. Springfield, IL: Charles C. Thomas.

Iso-Ahola, Seppo E., and Chun J. Park. 1996. "Leisure-Related Social Support and SelfDetermination as Buffers of Stress-Illness Relationship." Journal of Leisure Research 28(3):169-87.

Johnson, Heather A., Ramon B. Zabriskie, and Brian Hill. 2006. "The Contribution of Couple Leisure Involvement, Leisure Time and Leisure Satisfaction to Marital Satisfaction." Marriage and Family Review 40(1):69-91.

Jones, Ian. 2000. "A Model of Serious Leisure Identification: The Case of Football Fandom." Leisure Studies 19:283-98.

Kalmijn, Matthus, and Wim Bernasco. 2001. "Joint and Separated Lifestyles in Couple Relationships." Journal of Marriage and Family 63(3):639-54.

Kelly, John R. 1983. Leisure Identities and Interactions. London: Allen \& Unwin. 
Kelly, John R. and Valeria J. Freysinger. 2000. $2 I^{\text {st }}$ Century Leisure. Allyn and Bacon. Boston, MA.

Kyle, Gerard, and Garry Chick. 2002. "The Social Nature of Leisure Involvement." Journal of Leisure Research 34(4):426-48.

Laurendeau, Jason. 2006. "He Didn't Go in Doing a Skydive": Sustaining the Illusion of Control in an Edgework Activity." Sociological Perspectives 49(4):583-605.

Laurendeau, Jason, and E. G. Van Brunschot. 2006. "Policing the Edge: Risk and Social Control in Skydiving." Deviant Behavior 27:173-201

Laurendeau, Jason and Nancy Sharara. 2008. "Women Could Be Every Bit As Good As Guys": Reproductive and Resistant Agency in Two "Action" Sports." Journal of Sport and Social Issues 32:24-47.

Lee, Jin-Hyung and David Scott. 2006. "For Better or Worse? A Structural Model of the Benefits and Costs Associated with Recreational Specialization." Leisure Sciences 28:17-38.

Lipscombe, Neil. 1999. "The Relevance of Peak Experience to Continued Skydiving Participation: A Qualitative Approach to Assessing Motivations." Leisure Studies $18: 267-88$

Llewellyn, David J. and Xavier Sanchez. 2008. "Individual Differences and Risk Taking in Rock Climbing." Psychology of Sport and Exercise 9:413-26.

Lyng, Stephen. 1990. "Edgework: A Social Psychological Analysis of Voluntary Risk Taking." The American Journal of Sociology 95(4):851-86.

Maxwell, Andrew H. 1998. "Motorcyclists and Community in Post-Industrial Urban America." Urban Anthropology 27(3-4):263-99.

McQuarrie, Fiona, and Edgar L. Jackson. 1996. "Connections between Negotiation of Leisure Constraints and Serious Leisure: An Exploratory Study of Adult Amateur Ice Skaters." Society and Leisure 19(2):459-81.

Mennesson, Christine. 2000. "Hard' Women and 'Soft' Women: The Social Construction of Identities among Female Boxers." International Review for the Sociology of Sport 35(1):21-33.

Meyer, Alan D. 2009. Why Fly? A Social and Cultural History of Private Aviation in Post-World War II America: 1945-1985. PhD dissertation, Department of History, University of Delaware.

Murthy, Dhiraj. 2008. "Digital Ethnography: An Examination of the Use of New Technology for Social Research." Sociology 45(5):837-55. 
Ninety-Nines, Inc. 2009. 2009-2010 Membership Directory. Oklahoma City: The Ninety-Nines, Inc.

Parker, S. 1976. The Sociology of Leisure. London: George Allen \& Unwin.

Patton, Michael Q. 1987. How to Use Qualitative Methods in Evaluation. Newbury Park, CA: Sage.

Patton, Michael Q. 1990. Qualitative Evaluation and Research Methods. Newbury Park, CA: Sage.

Price, Ian R. and Claire Bundesen. 2005. "Emotional Changes in Skydivers in Relation to Experience." Personality and Individual Differences 38:1203-11.

Raisborough, Jayne. 2006. "Getting Onboard: Women, Access and Serious Leisure." The Sociological Review 54(2):242-62.

Recours, Robin A., Marc Souville, and Jean Griffet. 2004. "Expressed motives for Informal and Club/Association-based Sports Participation." Journal of Leisure Research 36(1):1-22.

Rojek, Chris. 2000. Leisure and Culture, New York: St. Martin's Press.

Roster, C. A. 2007. "Girl Power and Participation in Macho Recreation: The Case of Female Harley Riders." Leisure Sciences 29:443-61.

Ryan, Richard M. and Edward Deci. 2000. "Self-Determination Theory and the Facilitation of Intrinsic Motivation, Social Development, and Well-Being". American Psychologist 55(1):68-78.

Scott, David and Geoffrey C. Godbey. 1992. "An Analysis of Adult Play Groups Social Versus Serious Participation in Contract Bridge." Leisure Sciences 14(1):47-67.

Shamir, Boas. 1992. "Some Correlates of Leisure Identity Salience: Three Exploratory Studies." Journal of Leisure Research 24(4):301-23.

Sharpe, Erin. 2005. "Delivering Communitas: Wilderness Adventure and the Making of Community." Journal of Leisure Research 37(3):255-80.

Sindoni, Robert V. 2004. Recreational Aviation and Mental Health Issues: Impulsivity and Fluctuating Attention. PhD dissertation, School of Social Work, New York University.

Siegenthaler, K.L., and Irma O’Dell. 2000. "Leisure Attitude, Leisure Satisfaction, and Perceived Freedom in Leisure within Family Dyads." Leisure Sciences 22:281-96. 
Stalp, Marybeth C. 2006. "Creating an Artistic Self: Amateur Quilters and Subjective Careers.” Sociological Focus 39(3): 193-216.

Stalp, Marybeth C., M. Elise Radina, and Annette Lynch. 2008. "We Do It Cuz It's Fun:" Gendered Fun and Leisure for Midlife Women Through Red Hat Society Membership." Sociological Perspectives 51(2):325-48.

Stebbins, Robert. 1992. Amateurs, Professionals, and Serious Leisure. Montreal, Canada: McGill-Queens University Press.

Stebbins, Robert A. 2004. "Erasing the Line between Work and Leisure in North America." Paper presented at the Leisure and Liberty in North America Conference, Paris, France, 12 November, 2004.

Stebbins, Robert. 2007. Serious Leisure: A perspective for our time. New Brunswick, NJ: Transaction Publishers.

Stebbins, Robert A. 2008. "Right Leisure: Serious, Casual, or Project-based?" NeuroRehabilitation 23:335-41.

Strauss, Anselm and Juliet Corbin. 1994. "Grounded Theory Methodology: An Overview." In N. Denzin \& Y. Lincoln (Eds.). Handbook of Qualitative Research (pp. 273-285). Thousand Oaks, CA: Sage.

Thorpe, H. 2005. "Jibbing the Gender Order: Females in the Snowboarding Culture." Sport in Society 8(1):76-100.

Unruh, David R. 1979. "Characteristics and Types of Participation in Social Worlds." Symbolic Interaction 2(2):115-29.

Valentine, Charles Alden. 2001. An Investigation of Task and Interpersonal Processes Supporting Women Remaining in General Aviation Flight Training. PhD dissertation, Massachusetts School of Professional Psychology.

Van Hiel, Alain and Maarten Vansteenkiste. 2009. “Ambitions Fulfilled? The Effects of Intrinsic and Extrinsic Goal Attainment on Older Adults' Ego-integrity and Death Attitudes." International Journal of Aging and Human 68(1):27-51.

Walker, Gordon J., Jinyang Deng and Rodney B. Dieser. 2005. "Culture, SelfConstrual, and Leisure Theory and Practice." Journal of Leisure Research 37(1):77-99.

Walker, Gordon J. 20008. "The Effects of Ethnicity and Gender on Facilitating Intrinsic Motivation during Leisure with a Close Friend." Journal of Leisure Research 40(2):290311. 
Walker, Gordon J. and Xiye Wang. 2008. "A Cross-Cultural Comparison of Canadian and Mainland Chinese University Students' Leisure Motivations" Leisure Sciences 30:179-97.

Wang, Philip. 2003. "Flying Fun: An Exploratory Examination of Serious Leisure." Pp. 219-222 In James Murdy, editor. Proceedings of the 2003 Northeastern Recreation Research Symposium. Gen. Tech. Rep. NE-317. Newtown Square, PA: U.S. Department of Agriculture, Forest Service, Northeastern Research Station.

Waterman, Alan S. 2005. "When Effort Is Enjoyed: Two Studies of Intrinsic Motivation for Personally Salient Activities." Motivation and Emotion 29(3):165-88.

Wearing, Betsy. 1998. Leisure and Feminist Theory. Thousand Oaks, CA: Sage.

Wheaton, Belinda. 2000. "Just Do It": Consumption, Commitment, and Identity in the Windsurfing Subculture." Sociology of Sport Journal 17:254-74. 


\section{CURRICULUM VITAE}

NAME:

ADDRESS:

DOB:

EDUCATION:

HONORS:
Frances Louise Shupe

Department of Sociology

Lutz Hall

University of Louisville

Louisville, KY 40292

Gettysburg, Pennsylvania - January 7, 1956

University of Louisville, Louisville KY

Sociology

Masters of Arts degree, August 2010

Virginia Commonwealth University

Interdisciplinary Studies

Bachelor of General Studies, August 1987

Graduate Teaching Assistantship, University of Louisville, $2009-2010$

Alpha Kappa Delta International Sociology Honor Society, University of Louisville, 2008-2010

PROFESSIONAL SOCIETIES :

American Sociological Association, 2008 - 2010

Sociologists for Women in Society, 2009 - 2010

Mid-South Sociological Association, 2009 - 2010

Southern Sociological Society, $2009-2010$ 